Chapman University

Chapman University Digital Commons

Economics Faculty Articles and Research

Economics

2011

\title{
Institutions, the Rise of Commerce and the Persistence of Laws: Interest Restrictions in Islam and Christianity
}

Jared Rubin

Chapman University, jrubin@chapman.edu

Follow this and additional works at: http://digitalcommons.chapman.edu/economics_articles

Part of the Growth and Development Commons, History of Religions of Western Origin

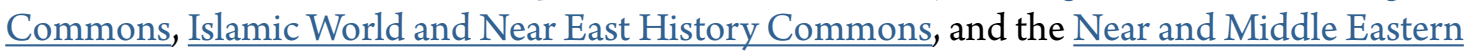
Studies Commons

\section{Recommended Citation}

Rubin, Jared. "Institutions, the Rise of Commerce and the Persistence of Laws: Interest Restrictions in Islam and Christianity*" The Economic Journal 121.557 (2011): 1310-1339.

DOI:10.1111/j.1468-0297.2011.02456.x

This Article is brought to you for free and open access by the Economics at Chapman University Digital Commons. It has been accepted for inclusion in Economics Faculty Articles and Research by an authorized administrator of Chapman University Digital Commons. For more information, please contact laughtin@chapman.edu. 


\section{Institutions, the Rise of Commerce and the Persistence of Laws: Interest Restrictions in Islam and Christianity}

\section{Comments}

This is the accepted version of the following article:

Rubin, Jared. "Institutions, the Rise of Commerce and the Persistence of Laws: Interest Restrictions in Islam and Christianity*." The Economic Journal 121.557 (2011): 1310-1339.

which has been published in final form at DOI: 10.1111/j.1468-0297.2011.02456.x.

\section{Copyright}

Wiley 


\title{
Institutions, the Rise of Commerce, and the Persistence of Laws: Interest Restrictions in Islam \& Christianity*
}

\author{
Jared Rubin \\ California State University, Fullerton
}

\begin{abstract}
Why was economic development retarded in the Middle East relative to Western Europe, despite the Middle East being far ahead for centuries after the fall of Rome? A theoretical model inspired and substantiated by the history of interest restrictions suggests that this outcome emanates in part from the greater degree to which early Islamic political authorities derived legitimacy from religious authorities relative to those in Europe. This entailed a feedback mechanism in Europe in which the rise of commerce led to the secular (and eventually religious) relaxation of interest restrictions while also diminishing the Church's ability to legitimize political authorities. These interactions did not occur in the Islamic world despite equally amenable economic conditions.
\end{abstract}

\footnotetext{
*This paper is derived from chapter three of my dissertation, completed at Stanford University. I am extremely grateful to Avner Greif and Timur Kuran for helpful guidance, comments, and insight. I also wish to thank Ran Abramitzky, Latika Chaudhary, Antonio Ciccone, Metin Coşgel, Larry Iannaccone, Murat Iyigun, Michael Makowsky, Gavin Wright, three anonymous referees, and participants in workshops at Cal State Fullerton, George Mason University, Stanford University, UC-Irvine, University of Connecticut, the 2007 EHA and ASREC Meetings, and the 2009 ASSA Meetings. I am greatly indebted to funding received from the Center for the Economic Study of Religion and the Mercatus Center. All errors are mine.
} 


\section{Introduction}

Over the past few decades, a significant amount of research has been conducted in search of the causes underlying the "rise of the West" (North and Thomas 1973; Jones 1981; Diamond 1997; Landes 1998; Pomeranz 2000; Acemoglu, Johnson, and Robinson 2005; Greif 2006; Clark 2007). In relation to the Middle East, such research takes on a special significance. By almost any account, the Middle East was far more advanced economically and scientifically than Western Europe as late as the thirteenth century, yet Middle Eastern economies did not develop nearly as rapidly as Western European ones did in the ensuing centuries and were far surpassed economically after the Industrial Revolution (Ibn Khaldun 1379/1958; Mokyr 1990; Kuran 1997; Lewis 2002). ${ }^{1}$ Perhaps instead of searching for the factors underlying the rise of the West, the correct question to pose is the converse one Bernard Lewis (2002) suggests: "What went wrong?"

Until recently, popular explanations for the economic divergence, especially those espoused by Max Weber, suggested that the "conservative" or "mystical" nature of Islam discouraged curiosity (to learn non-Muslim languages or European cartography, take foreign expeditions, adopt foreign methods and techniques, and so forth) and prevented risk-taking, innovation, and mechanization (Weber [1922] 1978; Cromer 1908; von Grunebaum 1966; Lewis 1982, 2002). In this view, Islam is seen as inherently hostile to commerce and finance. ${ }^{2}$ Indeed, there are numerous historical phenomena which, on the surface, encouraged this line of analysis. In particular, both religions advocated several laws which inhibited economic development -

\footnotetext{
${ }^{1}$ Throughout this paper, I use the terms "Christian world" and "Western Europe" to denote the pre-Reformation Christianized regions under the Church of Rome. I use the term "Islamic/Muslim world" somewhat broadly, comprising North Africa and the "Middle East" (that is, the entire Arab world, Iran, Turkey, the Balkan Peninsula, and Spain up to the Reconquista). Muslim regions of Central Asia, the Indian subcontinent, and the Malay Peninsula are not the direct focus of this paper, though the arguments are applicable to these regions.

${ }^{2}$ For an overview of this literature, see Kuran (1997, p. 49-53).
} 
such as regulations on taking interest and printing, suppression of women, and laws discouraging mass education. Although such laws were equilibrium outcomes in the pre-modern settings in which they emerged, they generally persisted for longer in Islam than in Christianity despite changing circumstances under which they inhibited economic activity.

Several theories have recently emerged that shed light on these divergent outcomes. Kuran $(1995,1997)$ suggests that social pressures in the Islamic world encouraged individuals to falsify their preferences. In this view, European financial instruments and organizational forms that were known to Muslims could not be discussed and certainly not adopted. Greif (1994) contends that cultural differences - Christian "individualism" versus Islamic "collectivism" - led to the emergence of different institutional forms in which contract enforcement and coordination based on legal, political, and economic organizations prevailed in Europe instead of the smallgroup sanctions seen in the Islamic world. Ekelund, Hébert, and Tollison (1989) and Ekelund et al. (1996) suggest that monetary incentives drove the medieval Church's actions. Though they are not concerned with the Islamic world per se, their argument can easily be extended to suggest that differing monetary incentives led to differential relaxation of religious laws in the two regions. $^{3}$

Devoid of any historical context, any of these differences may have entailed that economically inhibitive laws were more likely to persist in the Islamic world than in Western Christendom. Yet, if any of these hypotheses could be considered the driving force behind the divergence in economically inhibitive laws, they must be able to account for one of the most ubiquitous of such laws - restrictions on taking interest (usury) on loans. ${ }^{4}$ Such restrictions

\footnotetext{
${ }^{3}$ See Rubin (2008) for an extended discussion of other hypotheses that could explain the divergence in economic outcomes in the Christian and Islamic worlds.

${ }^{4}$ Though the terms interest and usury have different meanings in their modern context, in pre-modern times they were largely synonymous, and will thus be used interchangeably throughout the paper (Divine 1959; Persky 2007).
} 
prevailed in both religions throughout the medieval period and had an immense impact on the institutional structure and the types of financial instruments employed in both regions (de Roover 1948; Noonan 1957; Kuran 1986; Munro 2003, 2008; Rubin 2010; Koyama 2010). ${ }^{5}$ However, there are numerous phenomena associated with interest regulations for which these and other proposed hypotheses cannot account. For example, why were Islamic interest restrictions initially more relaxed than Christian ones, but Islamic restrictions persisted while Christian restrictions eroded? Why did the Christian Church maintain its interest prohibition for centuries after commerce re-emerged in Western Europe?

This paper suggests an alternative solution which can account for numerous aspects of Islamic and Christian interest histories. I argue that the differential persistence of economically inhibitive laws in general, and interest restrictions in particular, resulted from the greater degree to which early Islamic political authorities depended on conforming to the dictates of religious authorities for legitimacy. Religious legitimization has historically been extremely important for political authorities in both religions, permitting them to extract more from the populace, discouraging revolt, and enabling access to property rights assignment (Mann 1986; Greif 2002, 2006). ${ }^{6}$ Although the degree of dependence on religious legitimization is endogenous over time, I argue that the initial differences between the Islamic and Christian worlds were an exogenous remnant of the circumstances surrounding each religion's birth. The unintended, endogenous consequences of this exogenous difference on equilibrium outcomes are thus amenable to a theoretical analysis which falls into a broader literature seeking exogenous roots of institutional

\footnotetext{
${ }^{5}$ On the other hand, many scholars have argued that because interest restrictions were easily evaded, they 'belong less to economic history than to the history of ideas' (quoted in Kindleberger 1980, also see Labib 1969; Rodinson 1973; Udovitch 1975; Le Goff 1979; Jones 1988; Pamuk 2004).

${ }^{6}$ For more on the role that religious authorities have played in legitimizing the state in the Islamic and Christian worlds, see Mann (1986), Tierney (1988), Greif (2002, 2006), Coşgel and Miceli (2009), Coşgel, Miceli, and Ahmed (2009), and Coşgel, Miceli, and Rubin (2010).
} 
and economic differences (Diamond 1997; Kuran 2001, 2003, 2005; Acemoglu, Johnson, and Robinson 2001, 2005; Engerman and Sokoloff 2002).

Moreover, unlike works directly connecting religious beliefs (Weber [1905] 2002; Tawney [1926] 1954; Barro and McCleary 2003; Guiso, Sapienza, and Zingales 2003) or religious education (Becker and Woessmann 2008, 2009; Botticini and Eckstein 2005, 2007; Meyersson 2009; Chaudhary and Rubin 2010) to economic outcomes, this paper seeks an institutional pathway connecting initial, exogenous religious institutional structures to differences in economic development. In turn, it provides a connection between Islam and underdevelopment that does not rely on any feature of religion itself. ${ }^{7}$

In order to shed light on the unintended consequences of these exogenous institutional differences, I construct a theoretical model containing three salient features: 1) the existence of a productive action (such as lending at interest) which is regulated by political and religious authorities, 2) political authorities are dependent on religious authorities for legitimacy, and 3) the degree of this dependence is endogenously determined, although the initial level is exogenous. The model does not attempt to explain why the initial institutional differences emerged, as they are viewed as exogenously given. Instead, the model analyzes how an exogenous increase in the returns to production (such as the emergence of capitalistic markets allowing for investment lending) endogenously affects the interactions between political and religious authorities under varying degrees of exogenous "initial" dependence. That is, it shows how both religious laws and the endogenous degree of dependence are in part determined by exogenous initial conditions (the initial degree of dependence).

\footnotetext{
${ }^{7}$ This paper thus provides an alternative explanation for findings of cross-country regressions connecting religion, and especially Islam, to economic development (Grier 1997; Barro and McCleary 2003; Guiso, Sapienza, and Zingales 2003). For a different view, see Noland (2005).
} 
I show that when the initial level of dependence is large, institutions which support economically inhibitive laws are more likely to be self-enforcing. The intuition underlying this result begins with political authorities in "low-dependence" economies having greater incentive to relax regulations on productive actions that are highly regulated by religious authorities. In these economies, the religious authority also has greater incentive to relax its regulation, as it stands to lose influence or funding from the political authority otherwise. Moreover, since the religious authority reinterprets its supposedly "eternal doctrine", the legitimizing relationship is undermined to a greater extent, resulting in an endogenous change of dependence.

The model also helps explain other, counter-intuitive aspects of interest history. For one, it provides a rationale for why the Christian Church maintained an interest ban for centuries after the onset of the Commercial Revolution, only to relax laws in the $14^{\text {th }}-15^{\text {th }}$ centuries. It suggests that the Church relaxed laws only after its legitimizing relationship with political authorities was endogenously undermined over time by the rise of commerce. Moreover, the model also helps explain why Islamic interest restrictions were initially more relaxed but eventually stricter than Christian regulations. It suggests that early commercial pressures encouraged Islamic reinterpretation of interest doctrine, but because of the high level of dependence, the restrictions were not fully alleviated and the subsequent levels of dependence were not endogenously undermined. On the other hand, the relatively low levels of initial dependence in Christianity meant that once commerce was reborn in Europe, endogenous processes commenced which eventually undermined both religious interest restrictions and the legitimizing relationship between political and religious authorities.

Finally, the model has implications that extend well beyond the history of interest restrictions. Most importantly, it provides a distinction between observed conservatism, which is 
an outcome, and inherent conservatism, which is part of the preference set. It provides testable predictions which show that conservative outcomes may emerge not from a preference for conservatism or an inherent resistance to change (as was the preferred explanation of the Weberian school), but instead from the legitimizing relationship between political and religious authorities. In turn, the analysis of this relationship sheds a new light on why the ingenuity associated with early Islamic legal doctrine ultimately stagnated.

\section{Interest Restrictions in Islam and Christianity}

\subsection{Interest Restrictions in Western Christianity}

The Church's ban on taking interest emerged in the fourth century C.E. and officially became doctrine in 325 when it was included in Canon 17 of the first Ecumenical Council (Nicæa). The ban was supported by subsequent Church councils, establishing the basis for the "campaign against usury" in the medieval period.

With European commerce stagnating and most loans being taken for consumption prior to the tenth century, there was little need for the Church to re-consider its interest prohibition. When commerce revived, however, investment lending became more important - as Robert S. Lopez (1971, p. 72) notes, "unstinting credit was the great lubricant of the Commercial Revolution." Yet, in this period the Church actually maintained the interest ban, issuing decrees at the Second, Third, and Fourth Lateran Councils $(1139,1179$, and 1215) which proscribed excommunication for usurers, refused usurers burial in Christian grounds, and interdicted usurers' offerings (Le Goff 1979; Munro 2003, 2008). In 1234, Pope Gregory IX (1227-1241) issued his Decretales, which forever classed usurers as infames (making them ineligible to hold public office, honors, or to testify in court), commanded princes to expel usurers from their 
realms, forbade landlords from renting property to usurers, and invalidated the wills and testaments of usurers (Munro 2003, 2008). Throughout the twelfth and thirteenth centuries, the Church's "campaign against usury" crystallized into a staunch prohibition in any form, and the money-lender was linked with the worst type of evil-doers.

Despite these condemnations, a growing number of secular authorities permitted moderate interest in the thirteenth century, setting laws that merely capped the legal interest rate. ${ }^{8}$ Several rulers at least partially promulgated these laws for personal reasons - there are many accounts of rulers needing access to credit, which was often obtained through forced loans (Munro 2003). Such loans, which were also known in Venice, Genoa and Florence since the thirteenth century, were uncontestable and received relatively small interest (Lane 1966, ch. 6; Mueller 1997, ch. 10-14). Larger loans made by entrepreneurs (which were also often forced) to secular authorities were risky and default was common, and this was reflected in the interest rate they received.

From the twelfth century forward, the Church explicitly prohibited manifest usury, or low-risk credit extended on collateral. This prohibition applied primarily to pawn-brokers and lombards (who lent for consumption) and was generally not imposed on the merchant-bankers who dealt in financial instruments with non-guaranteed interest. This left the door open for religious authorities to permit (through theoretical manipulation) commercial practices which were in spirit similar to lending at interest but were not riskless and hence not considered manifest usury. Early alternatives to guaranteed loans at interest included partnerships (societas or commenda) and the census (or rente), an annuity on a fruitful good which often funded public finance. These contracts had features implicit in interest-bearing loans and grew deeply

\footnotetext{
${ }^{8}$ In different locales, different types of legal systems were employed to uphold such laws. Mercantile law was especially important in facilitating contracts which either implicitly or explicitly included a title to interest. See Berman (1983, ch. 11). For a sample of such laws, see Rubin (2010).
} 
embedded in commercial relations. They were eventually justified by religious authorities in the fourteenth and fifteenth centuries as legitimate within the context of Christian thought, centuries after they were permitted by secular authorities (Noonan 1957, ch. 6-7). ${ }^{9}$ Likewise, bills of exchange incited controversy amongst the Scholastics (religious scholars). Bankers used the bills to make low-risk profit by taking advantage of differences in exchange rates across regions (de Roover 1963). However, religious authorities were willing to accept their validity in the fifteenth century, centuries after their secular legality was assured and they became entrenched in European finance (Noonan 1957).

Closer substitutes to interest-bearing loans emerged in subsequent centuries, including the triple contract, ${ }^{10}$ mortgage, and fictitious sales. These contractual forms were eventually justified by Christian religious authorities, often by resolving them into other, lawful contracts (Noonan 1957; Divine 1959; Gilchrist 1969). ${ }^{11}$ A final blow to anti-usury doctrine occurred at Lateran V (1512-17), when the Church officially sanctioned the monte di pietà, or pious pawn bank. The ban was officially lifted in a series of decisions between 1822 and 1836 (though it had long been a dead letter) in which the Holy Office publicly declared moderate interest legal to everyone. In 1917 the Church offered the Codex iuris canonici, which replaced all earlier collections of canon law and allowed a legal title to interest (Noonan 1957).

\subsection{Interest Restrictions in Islam}

\footnotetext{
${ }^{9}$ The first arguments by Church authorities favoring the societas appear in 1270, but the broader relaxation of restrictions on partnerships arose in the following centuries (Noonan 1957). Innocent IV declared rentes legitimate in 1251, but this issue was hotly debated and not fully resolved for two more centuries (Munro 2008).

${ }^{10}$ The triple contract was made up of three different types of transactions: a contract of partnership (societas), insurance on the principal of the partnership, and a contract where an uncertain future gain is sold for a lesser certain gain. Each individual contract was valid, but when combined, simulated a risk-free loan.

${ }_{11}$ The scholastics permitted these practices by appealing to theoretical concepts such as lucrum cessans (literally "profit ceasing", a pre-Smithian term for the opportunity cost of lent money), damnum emergens (loss occurring due to not having lent money), and interesse (originally a penalty paid for late repayment), all of which quickly gained currency in theological circles and presaged the Church's official relaxation of the ban (Noonan 1957, ch. 5, 12).
} 
The prohibition of interest $(r i b \bar{a})$ has always been a cornerstone of Islamic doctrine. The Qur'ān contains numerous injunctions forbidding ribā, which in pre-Islamic times was a usurious process in which the principal sum was doubled and re-doubled (Rahman 1964; Schacht 1995).

In the early Islamic period, commerce thrived to a much greater extent than in Europe, and lenders frequently employed straight-forward devices (hiyal) designed to facilitate evasions of the ban (Khan 1929; Schacht 1964, 2006; Coulson 1969; Grice-Hutchinson 1978; Ray 1997). Most of these devices were not only permitted by religious authorities but were also created by them. A famous example of a hiyal is the double sale (mukhätara), in which the prospective debtor sells to a creditor some commodity for cash, then immediately buys it back for a greater sum payable at a later date. This essentially amounts to a loan at interest, with the interest being the difference between the two prices. This simple stratagem was known in Medina as early as the eighth century.

Documentary evidence reveals that transactions involving overt, guaranteed interest were not a common means of extending commercial credit in early and medieval Islam (Udovitch 1979). In a detailed study of the early twelfth-century Cairo Geniza, Goitein (1967, p. 170) observes that although credit and commerce flourished in Egypt, "even a cursory examination of the Geniza material reveals that lending money for interest was not only shunned religiously, but was also of limited significance economically ... therefore, the economic role of financial investment today was then fulfilled by various forms of partnerships." ${ }^{12}$ By the mid-twelfth century, contracts stipulating interest can be found, but they were either derived from another type of contract or concealed in another way (Goitein 1967). Illicit transactions could be brought

\footnotetext{
${ }^{12}$ Partnerships, which were the most common form of credit extension and were widespread within the first few Islamic centuries, most frequently took the form of mudäraba (sleeping partnership) or 'inān, in which both partners invested some capital (Goitein 1967; Labib 1969; Udovitch 1970). For an extended analysis of partnerships in the medieval Islamic world, see Udovitch (1970).
} 
to court where they were generally voided without further legal consequence (Gerber 1999, p. $129,141)$.

Under the Ottomans, more straight-forward interest-bearing lending was permitted. For example, the Ottoman muftī Ebu's-su'ud (c. 1490-1574) permitted lending at moderate interest (though charging greater than 15 percent was considered a criminal offense) under the euphemistic designations "transaction" or "legal transaction" (Imber 1997, p. 146). Jennings (1973) shows convincing evidence, in a study of seventeenth-century judicial records in Anatolian Kayseri, that interest was regularly charged on credit in accordance with the Islamic law and "secular" law (kanun) and with the consent and approval of the judge's $(k \bar{a} d \vec{\imath})$ court, the religious scholars ('ulamā'), and the sultān. These records indicate that $20 \%$ per annum was considered acceptable and in accordance with the sharī'a. Almost all interest-bearing transactions Jennings observes involved some sort of ruse, the most popular of which was istiğlal, which involved the debtor giving his creditor a piece of real estate, supposedly as a sale, but actually as a pawn (Gerber 1988, ch. 7). It is unlikely that most lenders actually resorted to such tricks, however. Indeed, many scholarly works indicate that lip-service paid to sharī'a prevailed throughout the Ottoman Empire. ${ }^{13}$

Yet, the interest ban has never been fully alleviated in Islam. Direct breaching of the interest prohibition has always been considered a deadly sin and remains so in modern times, even if, as a practical matter, interest has been de facto legal for centuries.

\footnotetext{
${ }^{13}$ Imber (1997) argues that the fact that waqf trustees required borrowers to deposit a pledge suggests that they lent at interest directly. Likewise, Çizakça (1995) shows that the instruments used by the cash waqfs in Bursa were approved by the courts, but their relatively constant returns suggest that economic interest prevailed. Gerber (1988, ch. 7) shows that interest ranging between 10 to 15 percent was considered legal in seventeenth-century Bursa, but such transactions were primarily conducted via ruses (mainly istiğlal). Other common ruses, such as the "wool-sale" (where a piece of wool is purchased with the price being an interest payment) and resale with a stated profit (murabaha), attest that transactions conformed with the letter of the law in this period, even though interest-bearing lending was de facto legitimate.
} 


\section{A Hypothesis: Legitimacy and Institutions}

Is it possible to account for differences in interest histories both between Islam and Christianity and within both religions over time? Though I do not claim that a mono-causal explanation exists for such complex phenomena, these histories provide numerous facts that any convincing hypothesis must account for. For example, why did the Church initially react to the onset of the Commercial Revolution by maintaining interest restrictions, only to relax these restrictions a few centuries later? Why were interest restrictions relaxed in the Ottoman Empire? Why were interest restrictions initially stronger in Christianity, but eventually stricter in Islam? Most importantly, why did interest restrictions dissipate in Christianity but not in Islam?

I suggest that the histories of economically inhibitive religious laws in general and interest history in particular can be explained by differences in the degree to which political authorities depended on religious authorities for legitimacy. In both regions, religious legitimization has historically been extremely important to political authorities, as it created an environment in which individuals believed in the content of the espoused rules as well as their efficacy in regulating economic exchange (Greif 2006). Legitimacy permitted secular rulers to extract more from the populace (though it also allowed religious authorities to extract from the rulers), discouraged revolt by both citizens and rivals to the throne, and increased the ruler's ability to assign property rights (Mann 1986; Greif 2002, 2006).

Although the degree of dependence over time is a function of the political and religious authorities' interactions with each other and is thus endogenous (and is modeled as such), I argue that the initial level of dependence stems from the birth of these religions and is thus exogenous to the specific doctrines in question. Early Christians were forced to live under Roman authority, where it was both unnecessary and infeasible to create a legal system based on religious 
principles, and early Church leaders advocated a separation between political and religious institutions (Mann 1986, ch. 10; Tierney 1988; Feldman 1997). The most famous support for this position is attributed to Jesus: "Render unto Caesar the things which are Caesar's, and unto God the things that are God's" (Matthew 22:21).

On the other hand, Islam was formed at a time of weak centralized power and tribal feuding in the Middle East. The response of the earliest Muslim caliphs to rival claims of power was to establish a system of "descendent-based legitimacy", which supported the Caliph's claim to rule via a blood relationship with Muhammad (Greif 2002). Later Muslim rulers (after the Umayyads) could not reasonably claim a blood-line to the Prophet, but this early history entailed a situation in which Islamic leaders could legitimize their rule by obeying Islamic dictates, or what Greif (2002) calls "faith-based legitimacy". Hence, early Muslim history led to Islamic ideals becoming those of the state, and there has never been a clear demarcation in the Islamic world between religious and legal authority like there was for much of Christian history (Lewis 1974, 1993, 1995; Kuran 2005). The exogeneity of these initial differences is argued forcefully by Tierney $(1988$, p. 7$)$, who suggests that

....as a society grows from primitive tribalism into an ordered civilization, a common religion permeates all its activities and helps to form its characteristic institutions. The rise of medieval Islam provides a typical example. In such circumstances the creation of political institutions quite separate from the organization of the accepted religion seems hardly conceivable. Christianity, on the other hand, irrupted into an ancient civilization that already had its own established hierarchy of government and its own sophisticated tradition of political thought based on non-Christian concepts. In the early centuries, therefore, the Christian church had to develop its own structure of governing offices, sometimes parallel to but always apart from those of the secular hierarchy.

This is not to imply that Christian rulers were never dependent on religious rulers for legitimacy or that Christian doctrine is not conducive to encouraging a legitimizing relationship. 
Indeed, early pre-Christian Jewish leaders ruled at the behest of religious authorities, and the papacy had a significant degree of power over lay rulers between the eleventh and thirteenth centuries. I merely suggest that initial differences in the circumstances surrounding the births of the religions led to differences, however small, that fundamentally affected the future relationship between political and religious authorities in the two regions.

But can this institutional difference account for all of the peculiarities of interest history? Although it does not directly contradict any of the facts, it does not obviously account for some of them. In order to explore this possibility, I build a theoretical model which captures the salient institutional elements of both religions and analyzes how changes in these elements, particularly the degree to which political authorities are legitimized by religious authorities, affect equilibrium actions and the sustainability of economically inhibitive religious laws. The model is not intended to shed light on why these initial differences in institutional relationships emerged as argued above, these differences emerged for historical reasons which are exogenous to the model. Instead, I analyze the effects of these exogenous differences.

\section{Model: Legitimacy, Institutions, and Regulations}

\subsection{One-Period Model}

In this section, I model the relationship between political and religious authorities to shed light on how their interactions affect secular and religious regulations, such as lending at interest. The model analyzes the consequences of exogenous events which affect the socially optimal level of regulation bestowed by the authorities. In the context of lending at interest, such an event 
could be the emergence of capitalistic markets allowing for investment lending. ${ }^{14}$ Indeed, Rubin (2009), Brenner (1983), and Glaeser and Scheinkman (1998) argue that laws banning interest were socially optimal in the context of a pre-modern economy with weak social safety nets and missing contingent markets. Moreover, Rubin (2009) suggests that the initial promulgation of Christian interest restrictions in the fourth century arose due to the self-interest of the Church, who acted as a social insurer facing commitment problems (it could not commit to not helping those who over-borrowed). However, none of these models explain why interest bans persisted in spite of changing economic circumstances, such as the Commercial Revolution, under which banning interest (full regulation) was no longer optimal. The present model thus focuses on the institutional relationships that determine the extent to which religious regulations are relaxed. It generates other, complementary predictions as well, relating to the timing of such religious relaxations as well as the conditions under which strict regulations become less severe in the long run.

Part of the explanation for the persistence of religious regulations (and religious laws in general) arises from the self-interested resistance of religious authorities to change their doctrine, as they derive much of their power from their monopoly on "eternal truth" (Rodinson 1973; Noonan 1993, 2005; Hallaq 2001). "Resistance to change" is modeled as a preference, not an outcome. One goal of the model is to provide testable predictions related to conservative outcomes that distinguish between whether they are rooted in a preference for "resistance to change" or other salient features of the relationship between political and religious authorities, especially the legitimizing role of religious authorities. To this end, the model employs historically motivated behavioral assumptions to generate testable predictions which help explain

\footnotetext{
${ }^{14}$ Another example is restrictions placed on the reproduction of words and images, which may have made sense prior to the invention of the printing press, but were clearly restrictive, especially in the Ottoman Empire, after the introduction of the press.
} 
the differential paths of interest regulations across the two religions as well as within the religions over time.

Consider an economy consisting of two players: a political authority $(\mathrm{P})$ and a religious authority (R). ${ }^{15}$ In Europe, the religious authority can be thought of as the Catholic Church, while in the Middle East, the religious authorities can be thought of as local jurisconsultants (muftīs), who are the primary source of legal and religious reinterpretation in Islam. ${ }^{16}$ These players interact in a one period game of complete information, choosing political and religious interpretations of laws, which can be thought of as the degree of regulation imposed on the action in question (such as lending at interest). The political authority chooses a regulation, $p$, to maximize its utility, which it derives from two sources: conforming to its intrinsic optima, $\bar{p}$, and conforming to the dictates of the religious authority, $r$. The parameter $\bar{p}$ can be thought of as the legal regulation which maximizes the surplus of the (unmodeled) citizenry. In this case, the tax base available to the political authority is decreasing in the distance its regulation is from $\bar{p}$.

\footnotetext{
${ }^{15}$ I omit the citizenry as a player for the sake of analytical simplicity, although Rubin (2008) considers such a model and derives similar results. One potential shortcoming of omitting the citizenry is that the model does not allow for coordination between the citizens and political authority or amongst the citizens themselves. This type of coordination could encourage political authorities to relax laws, although it would also require that citizens coordinate to decrease the importance of religious legitimacy. In any case, it is not clear why this would explain differences in the Middle East and Western Europe, as the latter was more individualistic while the former was more communal (Greif 1994), and hence one would expect coordination to be more feasible in the Middle East.

${ }^{16}$ It is reasonable to question whether it is appropriate to consider the game played in the Islamic world as one between political and religious authorities, since the latter were much more decentralized than in Christianity. Sunni Islam crystallized in its first few centuries into four primary schools of law, all separated geographically. Thus, much like Church leaders in Christianity, local religious authorities (muftis and 'ulama') provided dictates independent from political authorities (Masud, Messick, and Powers 1996; Berkey 2003; Hallaq 2005) - within the constraints of their legal tradition. Even though it certainly could have been possible for a rogue mufti to grant an opinion not in-line with his legal tradition, it is unlikely that such an opinion would have become part of the mainstream (which is of concern in the model), as it would have been quite unlikely to be upheld by ijma' (consensus), one of the four pillars of Islamic legal doctrine. We would expect that due to the decentralized nature of Sunni Islamic religious authority, there would be different rulings in areas with different commercial and political pressures (as is suggested by the model). Indeed, Rubin (2010) notes that two schools of Sunni Islam (Maliki and Shafi'i) explicitly forbade bills of exchange (safatij), fearing that they could be used usuriously, one school (Hanbali) permitted them as long as no fee was charged, and they were disapproved of, though permitted, by the Hanafi school. Thus, the broad comparative statics of the model should still hold - both across the two religions and over time in Islam - since similar institutional relationships and the same corpus of Islamic doctrine are shared in all Muslim regions.
} 
Thus, the closer the law is to $\bar{p}$, the more relaxed is the regulation. ${ }^{17}$ The regulation $p$ is continuous, as are all parameters, reflecting the idea that there are many possible degrees of regulation. For instance, in the case of interest laws, the political authority may choose to prohibit interest, permit interest, or allow interest as long as a sufficiently large transaction cost is undertaken (such as hiyal).

The political authority loses utility when it chooses actions that differ from those chosen by the religious authority $(p-r)$. The extent to which it loses utility from choosing such actions, denoted by $\gamma \in \mathbb{R}^{+}$, is interpreted as the exogenous degree to which the political authority derives legitimacy by conforming to the regulation of the religious authority. In other words, we can write the political authority's utility as:

$$
U^{P}=-(p-\bar{p})^{2}-\gamma(p-r)^{2} .
$$

The religious authority chooses its regulation, $r$, to maximize its utility, which it derives from two sources: conforming to its intrinsic optima, $\bar{r}$, and conforming to the political authority's law, $p$. The parameter $\bar{r}$ can be thought of as the religious authority's initial doctrine. This cost associated with diverging from $\bar{r}$ arises from the historical observation that both Christian and Islamic religious authorities have derived much of their power in society from their monopoly on "eternal truths" (Rodinson 1973; Noonan 1993, 2005; Hallaq 2001). The extent to which the religious authority loses utility from reinterpreting its eternal doctrine, denoted by $\alpha \in \mathbb{R}^{+}$, is interpreted as the degree of the religious authority's resistance to change. The religious authority also loses utility when its level of regulation diverges from that imposed by the political authority, $(r-p)$, as this decreases the religious authority's influence with the

\footnotetext{
${ }^{17} \bar{p}$ could be modeled endogenously, where the actions of the (unmodeled) citizenry reveal the potential surplus available to the political authority, and the more relaxed the political interpretation is, the more the citizens reveal. I have considered such a model in a previous version of this paper (Rubin 2008) and the qualitative results do not change when $\bar{p}$ is endogenous; instead, the results are exacerbated. I leave $\bar{p}$ as exogenous in the present model merely for purposes of analytical simplicity.
} 
political authority (Ekelund et al. 1996; Greif 2002). ${ }^{18}$ The religious authority's utility can be written as:

$$
U^{R}=-(r-p)^{2}-\alpha(r-\bar{r})^{2}
$$

I employ the Nash equilibrium concept and denote equilibrium actions with the superscript *. Assume without loss of generality that $\bar{r} \leq \bar{p} .{ }^{19}$ The first order conditions provide the following best responses:

$$
\begin{aligned}
& p^{*}=\frac{\bar{p}+\gamma r}{1+\gamma}, \\
& r^{*}=\frac{p+\alpha \bar{r}}{1+\alpha} .
\end{aligned}
$$

The Nash equilibrium actions are thus:

$$
\begin{aligned}
& p^{*}=\frac{(1+\alpha) \bar{p}+\alpha \gamma \bar{r}}{1+\alpha(1+\gamma)}=\bar{r}+\frac{(1+\alpha)(\bar{p}-\bar{r})}{1+\alpha(1+\gamma)}, \\
& r^{*}=\frac{\bar{p}+\alpha(1+\gamma) \bar{r}}{1+\alpha(1+\gamma)}=\bar{r}+\frac{\bar{p}-\bar{r}}{1+\alpha(1+\gamma)} .
\end{aligned}
$$

The model sheds light on how differences in resistance to change $(\alpha)$, dependence on religious authorities for legitimacy $(\gamma)$, and the surplus maximizing regulation $(\bar{p})$ affect equilibrium regulations. In particular, the model shows how religious and political laws change when such laws change from being socially optimal $\left(p^{*}=r^{*}=\bar{p}=\bar{r}\right)$ to suboptimal (when $\bar{p}$ increases).

It follows directly from (5) and (6) that $\frac{\partial p^{*}}{\partial \bar{p}}=\frac{1+\alpha}{1+\alpha(1+\gamma)}>0$ and $\frac{\partial r^{*}}{\partial \bar{p}}=\frac{1}{1+\alpha(1+\gamma)}>0$. That is, political and religious relaxation of regulations should follow the occurrence of exogenous shocks that increase the surplus available to the political authority. The intuition underlying these

\footnotetext{
${ }^{18}$ It is also possible that the religious authority is directly affected by setting regulations that differ from the surplus maximizing regulation, as this may affect its ability to extract rent from the populace (Duby 1980; Ekelund et al. 1996). However, adding this concern to the utility function does not affect the qualitative results of the model, as the religious authority indirectly receives disutility, through $(r-p)$, by choosing regulations which differ from the surplus maximizing one.

${ }^{19}$ This entails that $r^{*} \leq p^{*}$. I employ this inequality when taking first order conditions.
} 
results is that an increase in the surplus maximizing regulation encourages the political authority to relax its regulation, which, in equilibrium, encourages the religious authority to relax its regulation.

Inequalities (7) through (10) indicate that economies with religious authorities more resistant to change $(\alpha)$ and those with political authorities who have greater dependence on religious authorities for legitimacy $(\gamma)$ have less relaxed regulations. The intuition is straightforward: a greater resistance to change discourages religious authorities from choosing regulations differing from the initial doctrine, which leads to less relaxed political regulations in equilibrium. Meanwhile, an increase in dependence encourages political authorities to choose regulations closer to religious ones, which are in turn closer to initial doctrine in equilibrium.

$$
\begin{aligned}
& \frac{\partial p^{*}}{\partial \alpha}=-\frac{\gamma(\bar{p}-\bar{r})}{(1+\alpha(1+\gamma))^{2}}<0, \\
& \frac{\partial r^{*}}{\partial \alpha}=-\frac{(1+\gamma)(\bar{p}-\bar{r})}{(1+\alpha(1+\gamma))^{2}}<0, \\
& \frac{\partial p^{*}}{\partial \gamma}=-\frac{\alpha(1+\alpha)(\bar{p}-\bar{r})}{(1+\alpha(1+\gamma))^{2}}<0, \\
& \frac{\partial r^{*}}{\partial \gamma}=-\frac{\alpha(\bar{p}-\bar{r})}{(1+\alpha(1+\gamma))^{2}}<0,
\end{aligned}
$$

Inequalities (7) through (10) suggest that political and religious authorities in economies with greater religious resistance to change as well as those with greater dependence on religious authorities for legitimacy impose less relaxed regulations. On the one hand, the model supports the hypothesis outlined in the previous section that Islamic political and religious authorities ultimately had more conservative (less relaxed) regulations regarding interest due to the legitimizing relationship between the two. However, the model is not able to disprove the alternative hypothesis that this result emerged because of "inherent conservativeness" in Islam $(\alpha)$ - that Islamic authorities merely had a greater preference for resistant to change than 
Christian authorities. Indeed, the model suggests that the two are observationally equivalent. Moreover, there are important historical phenomena for which the model cannot account - for example, why were interest restrictions more relaxed in much of the Islamic world relative to western Europe for much of their shared history (until the $14^{\text {th }}-15^{\text {th }}$ centuries), only to become much more relaxed in western Europe? In order to shed light on such questions and differentiate between alternative hypotheses, I complicate the model slightly in the following section by endogenizing the dependence parameter $(\gamma)$.

\subsection{Two-Period Model with Endogenous Dependence}

The simplicity of the model presented in the previous section obscures some of the nuances that drive the relationship between political and religious authorities. In particular, it assumes that the degree to which political authorities depend on religious authorities for legitimacy, $\gamma$, is exogenous to the interactions between players. ${ }^{20}$ Yet, it is possible that part of the reason that religious authorities derive utility from conforming to initial doctrine and from imposing laws similar to those of political authorities is that doing so also strengthens their ability to legitimize political authorities. That is, the legitimacy bestowed by the religious authority may be strengthened or undermined by the interactions between the players, and thus the dependence parameter, $\gamma$, is endogenous.

In order to clarify how endogenous legitimacy affects actions and outcomes, I consider a two-period model similar to the one-period model analyzed in the previous section, where authorities have the same utility functions in each period as they do in equations (1) and (2). The level of dependence in period one, $\gamma_{1}$, is exogenous, but it is endogenously determined in period

\footnotetext{
${ }^{20}$ There is reason to believe that the resistance to change parameter $\alpha$ could also be endogenous, as conservative actions taken in one period may encourage even further conservative actions in the future, especially if other arguments are forgotten once they fall out of the mainstream (Kuran 1995). However, adding such a specification into the model would only exacerbate the same shortcomings of purely conservative arguments spelled out in the present model.
} 
two. The level of dependence in period two, $\gamma_{2}$, is a function of 1) the exogenous level of dependence in the previous period, 2) the degree to which the religious authority reinterprets "eternal" doctrine in period one, $\left(r_{1}-\bar{r}\right)^{2}$, and 3) the distance between the political and religious authorities' regulations in period one, $\left(p_{1}-r_{1}\right)^{2}$. The second factor stems from the historical observation that both Christian and Islamic religious authorities have generally derived both power as well as the ability to legitimize secular leaders from their monopoly on "eternal truths". When such truths are reinterpreted, the very nature of their authority is threatened (Rodinson 1973; Noonan 1993, 2005; Ekelund et al. 1996; Hallaq 2001). The third factor underscores the notion that religious authority itself is undermined when religious dictates are widely transgressed or misaligned with the actions of political authorities. Indeed, this is largely the reason why accommodating custom has historically been an open concern of Islamic and Christian religious authorities (Schacht 1964, p. 78-85; Noonan 1966, 1993, 2005; Rodinson 1973; Imber 1997; Libson 1997; Gerber 1999; Hallaq 2001; Zubaida 2003, ch. 1-3).

In this light, the dependence parameter follows the following path:

$$
\gamma_{2}=\gamma_{1}-\beta\left(r_{1}^{*}-\bar{r}\right)^{2}-\eta\left(p_{1}^{*}-r_{1}^{*}\right)^{2}
$$

where $\beta \in \mathbb{R}^{+}$and $\eta \in \mathbb{R}^{+}$are the relative weights placed on the two sources of legitimacy and $\gamma_{2}$ is constrained so that $\gamma_{2} \geq 0$.

I assume that religious and political authorities do not consider their second period utility when making their first period decisions. In other words, (11) represents the non-internalized dynamic costs associated with the religious authority's actions, whereas its utility function, seen in equation (2), represents its internalized, static costs. That is, the difference between $\alpha$ and $\beta$ is that $\alpha$, the inherent resistance to change, is internalized by religious authorities, whereas $\beta$ 
represents a non-internalized measure of the erosion of legitimizing ability that occurs over time as a result of religious authorities "changing" doctrine.

This specification is chosen in part because it allows for a tractable result but, more importantly, because period two can be interpreted as the "very long run". In fact, if players have a sufficiently high discount rate (which would be expected if the actual difference between periods one and two were many generations), the results presented here are qualitatively similar to a model where players take into account the discounted effect that their actions have on legitimacy. ${ }^{21}$ In reality, it often takes many years for the relationship between political and religious authorities to fundamentally change, and the political or religious authority in period one will generally be a different individual than in period two. In the terms of Greif and Laitin (2004), this means that $\gamma_{2}$ is a "quasi-parameter" - one that is exogenous to the players at any given point in time but endogenous to the game as a whole. This allows for the study of actions where the institutional setting is endogenously changing (slowly) over time. The institutional parameters (in this case, $\gamma_{2}$ ) are viewed by all players as exogenous, yet their actions unintentionally undermine or reinforce the very institutional structures which constrain their action set.

This framework employed in the present context explains why the religious authority may lose its ability to legitimize despite choosing actions that conform to the political authority. This occurs when $\beta$ is sufficiently large relative to $\eta$, meaning that the religious authority draws its long-run power to legitimize primarily from its hold on eternal truths. Greif (2002) notes, for example, that the ability of Islamic religious authorities to legitimize political authorities has often been undermined when it appeared that they favored political authorities over Islamic

\footnotetext{
${ }^{21}$ I have formulated an alternative model where players consider their discounted utility when making choices in period one and I show that this specification does not alter the comparative statics, though it does provide less tractable results. This model is available upon request.
} 
doctrine. The religious authority may choose such actions which eventually limit its ability to legitimize because it internalizes the static parameters represented in (2) but not the long-run, institutional parameters in (11).

The political and religious authority's regulations are the same in the first period as they were in equations (5) and (6) (replacing $\gamma$ with $\gamma_{1}$ ). This entails that the equilibrium level of dependence in period two is:

$$
\gamma_{2}=\gamma_{1}-\left(\frac{\bar{p}-\bar{r}}{1+\alpha\left(1+\gamma_{1}\right)}\right)^{2}\left(\beta+\alpha^{2} \eta\right) .
$$

The Nash equilibrium actions in period two are:

$$
\begin{aligned}
& p_{2}^{*}=\bar{r}+\frac{(1+\alpha)(\bar{p}-\bar{r})}{1+\alpha\left(1+\gamma_{1}-\left(\frac{\bar{p}-\bar{r}}{1+\alpha\left(1+\gamma_{1}\right)}\right)^{2}\left(\beta+\alpha^{2} \eta\right)\right)}, \\
& r_{2}^{*}=\bar{r}+\frac{\bar{p}-\bar{r}}{1+\alpha\left(1+\gamma_{1}-\left(\frac{\bar{p}-\bar{r}}{1+\alpha\left(1+\gamma_{1}\right)}\right)^{2}\left(\beta+\alpha^{2} \eta\right)\right)} .
\end{aligned}
$$

As in the previous section, consider first the effect of a change in the surplus maximizing regulation $(\bar{p})$. The model sheds light on how religious and political laws change when such laws change from being socially optimal ( $p^{*}=r^{*}=\bar{p}=\bar{r}$ ) to suboptimal (when $\bar{p}$ increases). Unlike in the one-period model, changes in the surplus maximizing regulation $(\bar{p})$ affect equilibrium actions through two avenues. First, such changes encourage the political authority to relax its interpretation because they directly affect the political authority's utility. Secondly, an increase in $\bar{p}$ negatively affects the legitimacy parameter, as it increases the distance between the religious authority's interpretation and optimal action, $\left(r_{1}^{*}-\bar{r}\right)^{2}$, and it increases the equilibrium distance between the political and religious regulations, $\left(p_{1}^{*}-r_{1}^{*}\right)^{2}$.

This setup provides testable predictions related to three aspects of the interactions between changes in political and religious laws and changes in the economic environment $(\bar{p}):$ i) 
the degree of change of religious laws; ii) the speed and timing of changes in religious laws; iii) the "reversal effect", whereby the one economy has more relaxed religious regulations (higher $r_{1}^{*}$ ) in the short run but stricter regulations (lower $r_{2}^{*}$ ) in the long run. These three features are discussed below.

\subsubsection{The Level of Change in Regulations}

It follows directly from (13) and (14) that an increase in the surplus maximizing regulation $(\bar{p})$ results in a relaxation of equilibrium regulation levels. This can be seen in inequalities (15) and (16):

$$
\begin{aligned}
& \frac{\partial p_{2}^{*}}{\partial \bar{p}}=\left(\frac{1+\alpha}{1+\alpha\left(1+\gamma_{1}\right)}\right)\left(1+\left(\frac{\alpha(\bar{p}-\bar{r})^{2}\left(\beta+\alpha^{2} \eta\right)}{1+\alpha\left(1+\gamma_{2}\right)}\right)\left(\frac{1}{\left(1+\alpha\left(1+\gamma_{1}\right)\right)^{2}}+\frac{2}{1+\alpha\left(1+\gamma_{2}\right)}\right)\right)>0, \\
& \frac{\partial r_{2}^{*}}{\partial \bar{p}}=\left(\frac{1}{1+\alpha\left(1+\gamma_{1}\right)}\right)\left(1+\left(\frac{\alpha(\bar{p}-\bar{r})^{2}\left(\beta+\alpha^{2} \eta\right)}{1+\alpha\left(1+\gamma_{2}\right)}\right)\left(\frac{1}{\left(1+\alpha\left(1+\gamma_{1}\right)\right)^{2}}+\frac{2}{1+\alpha\left(1+\gamma_{2}\right)}\right)\right)>0 .
\end{aligned}
$$

As in the previous section, the model also reveals how changes in resistance to change $(\alpha)$ and initial dependence on religious authorities for legitimacy $\left(\gamma_{1}\right)$ affect equilibrium levels of regulation. The comparative statics relating to the political and religious authority's choices in the first period are the same as they were in equations (7) through (10) (replacing $\gamma$ with $\gamma_{1}$ ). However, endogenizing $\gamma$ provides the following comparative statics in period two:

$$
\begin{gathered}
\frac{\partial p_{2}^{*}}{\partial \alpha}=-\frac{\bar{p}-\bar{r}}{\left(1+\alpha\left(1+\gamma_{2}\right)\right)^{2}}\left(\gamma_{2}+\frac{2 \alpha(1+\alpha)(\bar{p}-\bar{r})^{2}}{\left(1+\alpha\left(1+\gamma_{1}\right)\right)^{3}}\left(\left(1+\gamma_{1}\right) \beta-\alpha \eta\right)\right) \\
\frac{\partial r_{2}^{*}}{\partial \alpha}=-\frac{\bar{p}-\bar{r}}{\left(1+\alpha\left(1+\gamma_{2}\right)\right)^{2}}\left(1+\gamma_{2}+\frac{2 \alpha(\bar{p}-\bar{r})^{2}}{\left(1+\alpha\left(1+\gamma_{1}\right)\right)^{3}}\left(\left(1+\gamma_{1}\right) \beta-\alpha \eta\right)\right), \\
\frac{\partial p_{2}^{*}}{\partial \gamma_{1}}=-\frac{\alpha(1+\alpha)(\bar{p}-\bar{r})}{\left(1+\alpha\left(1+\gamma_{2}\right)\right)^{2}}\left(1+\frac{2 \alpha(\bar{p}-\bar{r})^{2}\left(\beta+\alpha^{2} \eta\right)}{\left(1+\alpha\left(1+\gamma_{1}\right)\right)^{3}}\right)<0, \\
\frac{\partial r_{2}^{*}}{\partial \gamma_{1}}=-\frac{\alpha(\bar{p}-\bar{r})}{\left(1+\alpha\left(1+\gamma_{2}\right)\right)^{2}}\left(1+\frac{2 \alpha(\bar{p}-\bar{r})^{2}\left(\beta+\alpha^{2} \eta\right)}{\left(1+\alpha\left(1+\gamma_{1}\right)\right)^{3}}\right)<0 .
\end{gathered}
$$


Equations (19) and (20) reveal that the degree of relaxation of regulations is decreasing in the exogenous initial level of dependence $\left(\gamma_{1}\right)$, while equations (17) and (18) indicate that the degree of relaxation of regulations is decreasing in the level of resistance to change $(\alpha)$ when $\beta$ is sufficiently large or $\eta$ is sufficiently small. The intuition underlying these results is straightforward: higher levels of initial dependence $\left(\gamma_{1}\right)$ encourage political authorities to choose regulations closer to religious authority's regulation, which in turn has two effects. First, it directly entails that the equilibrium choice of regulation is closer to initial doctrine $(\bar{r})$. Secondly, it provides incentive for the authorities to take first period actions that endogenously undermine the second period dependence parameter to a lesser extent. On the other hand, high levels of resistance to change $(\alpha)$ encourage religious authorities to choose regulations closer to initial doctrine, which in turn entails that equilibrium political regulations are closer to initial doctrine $(\bar{r})$. Yet, if $\eta$ is large, the equilibrium choice of strict regulation has the unintended consequence of undermining the religious authority's ability to legitimize (as $\left(p_{1}^{*}-r_{1}^{*}\right)^{2}$ is large in this case), and this negative effect on legitimacy can outweigh the direct effect that resistance to change has on the equilibrium level of regulation.

Moreover, inequalities (21) and (22) show that, on the margin, religious and political regulations become less relaxed in economies where the initial level of dependence $\left(\gamma_{1}\right)$ is high after there is a positive change in the surplus maximizing regulation. ${ }^{22}$ The intuition underlying this result is that political authorities with lower levels of dependence on religious authorities are more flexible and thus have greater incentive to relax their interpretations. This also has the indirect effect of endogenously decreasing second-period legitimacy $\left(\gamma_{2}\right)$, which further provides incentive for the political authority to relax its regulation. ${ }^{22}$ I do not discuss $\frac{\partial^{2} p_{2}^{*}}{\partial \alpha \partial \bar{p}}$ and $\frac{\partial^{2} r_{2}^{*}}{\partial \alpha \partial \bar{p}}$ in this section because their signs are ambiguous and these results do not factor in
the historical analysis. 


$$
\begin{aligned}
& \frac{\partial^{2} p_{2}^{*}}{\partial \gamma_{1} \partial \bar{p}}=-\frac{\alpha(1+\alpha)}{\left(1+\alpha\left(1+\gamma_{2}\right)\right)^{2}}\left(-1+2\left(1+\frac{2 \alpha(\bar{p}-\bar{r})\left(\beta+\alpha^{2} \eta\right)}{\left(1+\alpha\left(1+\gamma_{1}\right)\right)^{3}}\right)\left(1+\frac{2 \alpha(\bar{p}-\bar{r})^{2}\left(\beta+\alpha^{2} \eta\right)}{\left(1+\alpha\left(1+\gamma_{1}\right)\right)^{2}\left(1+\alpha\left(1+\gamma_{2}\right)\right)}\right)\right)<0, \\
& \frac{\partial^{2} r_{2}^{*}}{\partial \gamma_{1} \partial \bar{p}}=-\frac{\alpha}{\left(1+\alpha\left(1+\gamma_{2}\right)\right)^{2}}\left(-1+2\left(1+\frac{2 \alpha(\bar{p}-\bar{r})\left(\beta+\alpha^{2} \eta\right)}{\left(1+\alpha\left(1+\gamma_{1}\right)\right)^{3}}\right)\left(1+\frac{2 \alpha(\bar{p}-\bar{r})^{2}\left(\beta+\alpha^{2} \eta\right)}{\left(1+\alpha\left(1+\gamma_{1}\right)\right)^{2}\left(1+\alpha\left(1+\gamma_{2}\right)\right)}\right)\right)<0 .
\end{aligned}
$$

These inequalities do not suggest that religious authorities implement religious restrictions in an ad hoc manner. What they do suggest is that once a restriction (which may have been socially optimal at one point in time) is implemented, the flexibility that authorities have to relax the laws is a function of the broader institutional structure. Indeed, inequalities (21) and (22) merely indicate that higher levels of initial dependence dampen (but do not eliminate) the impact of changes in the economic environment $(\bar{p})$ on future policies $\left(p_{2}^{*}\right.$ and $\left.r_{2}^{*}\right)$. This does not mean that high-initial dependence or highly resistant to change economies are forever stuck in a "high-regulation" state, but that the level of the shock necessary to push them away from this equilibrium is larger.

In sum, the analysis presented in this section suggests that the following relationship exists between the degree of regulatory change and the parameters of the model:

PREDiCTION \#1: The degree to which religious and political authorities relax regulatory laws is decreasing in the initial level of dependence of political authorities on religious authorities for legitimacy as well as the resistance to change of the religious authority. ${ }^{23}$

\subsubsection{The Timing of Changes in Regulations}

Reconsider equations (15) and (16). Comparing these second period results to the first period statics $\frac{\partial p_{1}^{*}}{\partial \bar{p}}=\frac{1+\alpha}{1+\alpha\left(1+\gamma_{1}\right)}$ and $\frac{\partial r_{1}^{*}}{\partial \bar{p}}=\frac{1}{1+\alpha\left(1+\gamma_{1}\right)}$ reveals that $\frac{\partial p_{2}^{*}}{\partial \bar{p}}>\frac{\partial p_{1}^{*}}{\partial \bar{p}}$ and $\frac{\partial r_{2}^{*}}{\partial \bar{p}}>\frac{\partial r_{1}^{*}}{\partial \bar{p}}$. This is true because an increase in the surplus maximizing regulation $(\bar{p})$ affects period two actions through

${ }^{23}$ Greater resistance to change does not entail less relaxed laws if $\eta$ is sufficiently large, as is shown in equations (17) and (18). I do not belabor this point because it works in favor of my hypothesis that the relaxation of religious laws is tied more to the legitimizing relationship between political and religious authorities than it is to the willingness of religious authorities to change. 
its direct effect on the political authority's utility as well as through its endogenous effect on period two legitimacy, whereas it only affects period one actions through the former.

This outcome sheds light on the timing of policy change $\left(p_{2}^{*}\right.$ and $\left.r_{2}^{*}\right)$ following a change in $\bar{p}$. That is, political and religious regulations may not change much in the short run (period one) following a change in the surplus maximizing regulation $(\bar{p})$ but may change substantially in the long run (period two). Indeed, when resistance to change $(\alpha)$ or the initial level of dependence $\left(\gamma_{1}\right)$ are sufficiently large, the regulations of the political and religious authorities will not change significantly in period one after a change occurs in the surplus maximizing regulation $(\bar{p})$. However, if the "delegitimizing" parameters, $\beta$ and $\eta$, are large enough or the initial religious doctrine $(\bar{r})$ is sufficiently smaller than $\bar{p}$, then an increase in the surplus maximizing regulation $(\bar{p})$ will lead to significant deregulation (large $p_{2}^{*}$ and $r_{2}^{*}$ ) in period two. This occurs because the change in the surplus maximizing regulation endogenously undermines the dependence of the political authority on the religious authority for legitimacy. In other words, both authorities may remain adamant in regulating the action for a period of time after an exogenous shock increases productivity, but they will begin to relax their interpretation after the salient interactions undermine the legitimizing relationship between authorities. As I show in the next section, this insight sheds light on lay and religious views on interest in reaction to the Commercial Revolution in Europe.

This provides a prediction that does not arise from the simpler, one-period model. The one-period model did not provide a way of differentiating whether resistance to change (a preference) or dependence (an institutional feature) is the root cause of observed conservatism (an outcome). In this light, equations (15) and (16) provide a testable prediction which only arises when legitimacy is the salient force underlying differences in observed outcomes. This is, 
namely, that religious and political regulations may not be relaxed much in the short run (period one) in response to changes in the surplus maximizing level of regulation, but are relaxed significantly in the long run (period two). This occurs when the change in the surplus maximizing regulation endogenously undermines the ability of the religious authority to legitimize the political authority. It is only after the de-legitimizing occurs that the regulations are relaxed.

In sum, a second testable prediction arises from the model:

PREDICTION \#2: After a shock occurs that affects the surplus maximizing level of regulation, religious and political regulations may continue to be severe for some time. They will only begin to be relaxed after the religious authority's ability to bestow legitimacy is endogenously undermined.

\subsubsection{The "Reversal" Effect}

Finally, the model can also account for the "reversal effect", which occurs between two different economies when a religious authority in one economy is initially more restrictive (low $\left.r_{1}^{*}\right)$ than the other but becomes less restrictive over time (higher $r_{2}^{*}$ ). To see this, consider two economies, I (Islamic) and C (Christian), where all parameters are the same except for initial doctrine $(\bar{r})$ and initial dependence $\left(\gamma_{1}\right)$. Denote $\bar{r}^{j}$ and $\gamma_{1}^{j}$ the economy-specific parameters, for $j \in\{C, I\}$, and denote the religious authority's action $r^{j}$. Assume that $\bar{r}^{I} \geq \bar{r}^{C}$ and $\gamma_{1}^{I} \geq \gamma_{1}^{C}$.

It follows directly from (6) and (10) that if $\bar{r}^{I}$ is sufficiently greater than $\bar{r}^{C}$ relative to $\gamma_{1}^{I}-\gamma_{1}^{C}$, then the religious authority in economy I has a more relaxed regulation in period one (higher $r_{1}^{*}$ ). This is seen qualitatively in Figure 1, which graphs the religious authorities actions in the $\bar{r}^{I} \times \gamma_{1}^{I}$ plane (where the axes should be interpreted as $\bar{r}^{I}-\bar{r}^{C}$ and $\gamma_{1}^{I}-\gamma_{1}^{C}$, since $\bar{r}^{C}$ and $\gamma_{1}^{C}$ are placed at the origin). It is straight-forward to show that, given $\gamma_{1}^{I}$, there is a threshold level 
of $\bar{r}^{I}$ where any $\bar{r}^{I}$ above the threshold entails that the religious authority in economy I has a more relaxed period one regulation.

\section{[INSERT FIGURE 1 HERE]}

However, it is possible that a greater initial level of dependence $\left(\gamma_{1}^{I}\right)$, combined with a more relaxed initial doctrine $\left(\bar{r}^{I}\right)$, may be the very reason why the religious authority in economy I has a more restrictive regulation in period 2. This result arises because the second period dependence parameter endogenously diminishes by less in economy I. This follows directly from (12), and intuitively holds because the religious authority in economy I chooses actions in period one which are closer to both the initial doctrine and the political authority's action - thus endogenously undermining legitimacy to a lesser extent. That is, the factors that undermine legitimacy are less present in economies with greater levels of initial dependence and more relaxed initial doctrine, all else being equal.

This logic entails that a "reversal" happens in part of the parameter space. ${ }^{24}$ It is possible that the religious authority in economy I has a more relaxed regulation in period one $\left(r_{1}^{I}>r_{1}^{C}\right)$ but a less relaxed regulation in period 2. The range over which a reversal arises can be seen in Figure 1. In this range, the sufficiently large levels of both $\bar{r}^{I}$ and $\gamma_{1}^{I}$ entail that the dependence parameter in economy I does not endogenously decrease by much relative to the dependence parameter in economy $\mathrm{C}$. In economy $\mathrm{C}$, the relatively low levels of $\gamma_{1}^{C}$ and $\bar{r}^{C}$ mean that the religious authority chooses actions in period one which either diverge from initial doctrine or from the political authorities' action (or both), thus endogenously undermining dependence. Hence, a "reversal" can occur when the parameters which encourage a stricter regulation in period one (namely, $\bar{r}$ and $\gamma_{1}$ ) also work to undermine dependence.

\footnotetext{
${ }^{24}$ That a "reversal" happens in part of the parameter space, as shown in Figure 1, is straight-forward to prove. The proof has been omitted but is available upon request.
} 
The following prediction thus arises:

PREDICTION \#3: A "reversal" can happen between two economies, where the religious authority in the economy with a more relaxed initial doctrine $(\bar{r})$ and greater initial dependence $\left(\gamma_{1}\right)$ has a more relaxed regulation in period 1 but a less relaxed regulation in period 2. This can only occur if the dependence parameter is endogenously undermined less in this economy than it is in the other economy between the two periods.

\section{Interest History, Institutions, and Legitimacy in the Context of the Model}

In this section I employ the insights of the model to shed light on numerous aspects of interest history and changes in relations between political and religious authorities. I begin by discussing how the institutional histories relate to the level of change in interest history (Prediction 1) and proceed to analyze the timing of changes (Prediction 2) and the reversal effect (Prediction 3).

\subsection{Institutions and the Level of Change in Interest Laws in Islam and Christianity}

A convincing hypothesis must account for two stylized facts noted in section 2 regarding the level of change of interest doctrine. These are: i) interest was strictly banned until the fourteenth-fifteenth centuries in Christianity, when the Church began to relax interest laws; ii) even though interest laws were stricter in early Christianity than in early Islam, interest restrictions were never fully alleviated in Islam.

In the context of the model, the growth of commerce in the late-tenth through thirteenth centuries can be viewed as the event which sparked interactions between western European political and religious authorities. Prior to this period, loans were primarily taken for consumption, and hence usury laws were not necessarily inhibitive (Glaeser and Scheinkman 
1998; Rubin 2009). Yet, the emergence of capitalistic markets meant that investment lending was feasible and that interest restrictions thereby inhibited economic activity.

Access to credit continued to grow and commercial opportunities became more abundant at the height of the Commercial Revolution in the twelfth and thirteenth centuries (Lopez 1971). In terms of the model, this meant that regulations on taking interest were more detrimental to economic efficiency ( $\bar{p}$ increased), and secular authorities had greater incentive to legalize moderate interest, which they did throughout the continent. ${ }^{25}$ The model predicts that political authorities should have responded by relaxing their regulations in spite of religious condemnation. And indeed, the twelfth and thirteenth centuries saw a flurry of secularly approved, but religiously prohibited, innovations of commercial instruments - bills of exchange emerged as a commercial instrument of importance at the Champagne fairs, rentes were employed for public finance, and the Church-prohibited sea-loan was widely used (Berman 1983; Munro 2003, 2008). This is precisely what is predicted by inequality (21) - lower levels of initial dependence $\left(\gamma_{1}\right)$ exacerbate the impact of changes in the economic environment $(\bar{p})$ on future policies $\left(p_{2}^{*}\right)$.

These events eventually undermined (endogenously) the Church's authority vis-à-vis political authorities, as suggested by the model. Tierney (1988) and Feldman (1997) argue that ecclesiastical leaders lost much of their authority over secular rulers in the mid-to-late thirteenth century ( $\gamma$ decreased) as a result of the growth of secular power into national kingdoms, new theories of the state based on Aristotelian foundations, and movements of criticisms within the Church. The loss of ecclesiastical power in this period is perhaps best exemplified by the

\footnotetext{
${ }^{25}$ An alternative hypothesis is that secular leaders legalized interest as soon centralized states emerged rather than after dependence on religious authorities diminished. While states and secular law were indeed emerging in this period (Berman 1983), such a hypothesis would have difficulty explaining why previous secular leaders such as Charlemagne denounced interest.
} 
Avignon Papacy (1309-1377), where the papal chair was largely under control of the French monarch. It was only after this loss of legitimizing power $(\gamma)$ that the Church began to relax interest laws, as noted in section 2.

In the Islamic world, on the other hand, widespread commercial opportunities arose well before they did in Europe (Goitein 1967; Labib 1969; Udovitch 1975). It is thus misleading to compare the two regions at any one given point in time - instead, we should focus on the consequences of the semi-institutionalized enactment of interest restrictions in the Middle East and North Africa upon the adoption of Islam.

As noted in Section 2, devices for circumventing the interest ban (hiyal) were known from the first Islamic centuries. Despite their questionable legality, most hiyal were permitted by religious authorities, and many were even created by them. Yet, transactions involving guaranteed interest were not a common means of extending commercial credit in early and medieval Islam (Udovitch 1979). In terms of the model, early Islamic religious authorities did reinterpret doctrine, but their regulations remained restrictive. Why were interpretations initially flexible but ultimately stagnant?

Again, the model focuses our attention on the interactions between political and religious authorities. Within the first Islamic century, muftīs (the primary source of legal and religious reinterpretation in Islam) and other religious scholars gained considerable power as an independent legitimizing force (Masud, Messick, and Powers 1996; Berkey 2003; Hallaq 2005). In turn, early Islamic leaders, who attained and maintained their right to rule by obeying Islamic dictates (Greif 2002), faced significant costs from not complying with Islamic law ( $\gamma$ was very large). This meant that Muslim political authorities and lenders had little incentive to "push the envelope" of what was permissible, and hence overwhelmingly permitted and conducted 
transactions that could be construed as within the confines of religious law. In turn, such transactions were relatively inexpensive for Muslim religious authorities to permit, as they did not entail a significant reinterpretation of doctrine. This led to the emergence of an equilibrium in which lending at interest was permitted, but only if a sufficient transaction cost (hiyal or other cumbersome transaction) was undertaken. In terms of the model, religious regulations were more relaxed than the initial ban on interest $(\bar{r})$, but not by much.

This equilibrium entailed that little endogenous institutional change (related to the legitimizing relationship between religious and political authorities) occurred in the Islamic world after the first few Muslim centuries. Religious regulations on interest were partially relaxed and the exogenous level of initial dependence $\left(\gamma_{1}\right)$ was large, so no player had incentive to change actions much - and thus endogenously undermine dependence - without the presence of a large shock. This does not mean that political authorities faced no challenges, only that "faith-based" legitimacy remained extremely important in most Islamic polities and was unlikely to be undermined by endogenous factors.

These histories can now be compared in the context of the model. The high, exogenous initial level of (relative) dependence in the Islamic world provided little incentive for changes to occur in either interest laws or subsequent (endogenous) levels of dependence. On the other hand, the lower, exogenous initial levels of dependence in Christianity encouraged changes on both fronts, in turn entailing that interest restrictions persisted for much longer in Islam than in Western Christendom (Prediction 1).

Commercial pressures to relax interest restrictions existed earlier in the Middle East than in Western Europe. Hence, the relaxation of interest restrictions happened earlier in the Middle East. Yet, due to a higher degree of exogenous initial dependence in the Middle East, interest 
restrictions were not fully alleviated, and the endogenous processes that eventually undermined both Christian interest restrictions and the Church's ability to legitimize political authorities in Europe did not occur in the Islamic world. The model suggests that the endogenous erosion of dependence was more likely to happen in Europe, where the initial level of dependence was lower.

Once the dependence of political authorities on religious authorities for legitimacy eroded, Christian interest restrictions became relaxed. On the other hand, such an institutional change did not occur (at least to that extent) in much of the Islamic world, where interest restrictions are still a salient economic feature today. For instance, a significant factor underlying the recent rise of Islamic banking is that loans are formed in ways which do not officially constitute interest $(r i b \bar{a}){ }^{26}$

These histories provide evidence for the primary prediction of the model: higher degrees of exogenous initial dependence of political authorities on religious authorities for legitimacy encourage more severe religious regulations of productive actions in the long run. In more general terms, exogenous initial differences in institutional arrangements, however small, can encourage the relevant players to interact in such a manner that vastly different equilibria emerge over time.

\subsection{The Timing of Changes in Interest Laws}

As noted in Section 2, Christian interest restrictions were maintained in the twelfth and thirteenth centuries. On the surface, the rationale for this attitude is not obvious - why would the Church

\footnotetext{
${ }^{26}$ Moreover, institutional arrangements similar to those in the Ottoman period still exist today; state muftis were appointed in the twentieth century in Egypt, Saudi Arabia, Lebanon, Malaysia, Yemen, and Indonesia, and twentieth century constitutions in Egypt, Syria, Kuwait, Morocco and Iran (to name a few) include provisions making the shari’'a the law of the land (Schacht 1964, p. 107-110; Masud, Messick, and Powers 1996).
} 
maintain the prohibition just as access to credit was beginning to lubricate commerce? Does the model say anything about the timing of changes in Christian interest restrictions?

The model provides an explanation that relates the Church's maintained anti-usury stance to its increased legitimizing role. ${ }^{27}$ In general terms, Prediction 2 suggests that religious authorities may initially remain conservative after a positive economic shock such as the Commercial Revolution, but they will reinterpret doctrine after the interactions of the relevant players endogenously undermine the legitimizing relationship between political and religious authorities. That is, religious authorities will continue to strictly regulate the action for some time, as they incur a cost from reinterpreting "eternal" doctrine. In fact, the papacy and the Scholastics (religious scholars) cited such "eternal" doctrine, synthesized with Aristotelian thought, in their efforts to maintain the ban (Noonan 1957; Munro 2003).

The growth of commerce was at least partially responsible for the endogenous undermining of the legitimizing relationship between political and religious authorities, in the manner described in the model. Mann (1986) and Greif $(2005,2006$, ch. 4, 8, 12) argue that national kingdoms emerged due to the growing importance of commerce and medieval cities, not the Church. ${ }^{28}$ Merchants needed pacification between states and in foreign states and hence turned to secular leaders to provide such protection in return for loans or taxes. Pacification, in turn, fostered urban growth and the further development of trade, which necessitated more complex (and usurious) financial instruments. Mann (1986, p. 437) suggests:

\footnotetext{
${ }^{27}$ If anything, papal power increased in this period, but for reasons exogenous to the model. The papacy maintained significant power vis-à-vis secular authorities following the Papal Revolution led by Gregory VII in the late eleventh century and the resolution of the Investiture Controversy at the Concordat of Worms (1122). Both of these events gave the Church immense power until the end of the thirteenth century (that is, $\gamma$ was relatively large) (Berman 1983; Mann 1986; Tierney 1988; Feldman 1997).

${ }^{28}$ Lopez (1971), Jones (1997), and Greif (2006) similarly argue that the Italian city-states were built by merchants for merchants. Though religion was extremely important in the communes, the interests of religious authorities were generally subordinate to those of the merchant elite.
} 
By the twelfth century, economic growth was generating technical problems involving more complex economic relations between strangers to which the church was more marginal. The closer relationship between markets, trade, and property regulation, on the one hand, and the state, on the other, gave the state new resources that it could use to enhance its own power, especially against the papacy.

One link made in this paper is that the growth of national kingdoms and commerce was in part made possible by widespread secular alleviation of anti-interest dictates. On the one hand, employment and secular acceptance of prohibited financial instruments and transactions was essential for the commercial growth that preceded the rise of kingdoms and cities. ${ }^{29}$ On the other hand, these events also endogenously undermined the Church's power over secular authorities. These two forces reinforced each other until a new equilibrium emerged - as more profitable commercial opportunities became available, merchants further evaded the Church's dictates and sought protection from secular authorities. This provided greater incentive for rulers to provide security and legalize interest, as it decreased the importance of religious legitimacy $(\gamma)$ and increased the profitability of credit extension $(\bar{p})$. Hence, the Church's loss of power vis-à-vis secular rulers was itself both a cause and a consequence of the rise of commerce and the resulting interactions between merchants, the Church, and political authorities.

Although the Church initially responded to the Commercial Revolution by maintaining its anti-usury stance, this had the unintended consequence of eventually diminishing its ability to legitimize political authorities. Prediction 2 suggests that, in turn, the Church should begin to relax interest restrictions only after its legitimacy was endogenously undermined. In fact, it was only after the importance of the legitimizing relationship eroded in the mid-thirteenth century

\footnotetext{
${ }^{29}$ Conversely, Berman (1983, p. 338) argues that the Church encouraged commerce in this period, noting that the Church "encouraged the pursuit of money or riches provided that such pursuit was carried on for certain ends and according to certain principles." This line of thought is not completely contradictory to the argument made in this paper, however. I never claim that the Church opposed profit or was even ultimately inflexible in its views on interest. Instead, I suggest that this flexibility was only realized after merchants transgressed some of the Church's stricter dictates.
} 
that political authorities relaxed their restrictions, and the Church followed suit over the subsequent centuries. The "campaign against usury" halted in the late-fourteenth and fifteenth centuries and the Church slowly began to permit alternatives to interest thereafter. By the end of the fifteenth century, religious authorities permitted even more openly usurious practices such as bills of exchange and the triple contract. The timing of changes of Christian interest restrictions thus accords with the model's intuition - as secular dependence on the Church endogenously diminished in medieval Europe, political and religious authorities relaxed interest restrictions, and the institutions supporting the ban were undermined.

This history also provides evidence in favor of the primacy of legitimizing relationships $(\gamma)$ over inherent resistance to change $(\alpha)$ in the determination of religious and political laws. Prediction 2 indicates that when the legitimizing relationship is important, a lag between economic shocks (such as the Commercial Revolution) and changes in religious interpretations may occur, as the shock leads to interactions which over time undermine the ability of religious authorities to legitimize. On the other hand, there is no clear avenue through which an inherent resistance to change has the same effect on equilibrium outcomes. Hence, the model provides a prediction - supported by the history - whereby institutional features and not conservative preferences are shown to be the driving force behind conservative outcomes.

As explained above, endogenous institutional change like that experienced in Western Europe was less likely to occur in the Islamic world, since the initial level of dependence was much greater in the latter. Yet, a "natural experiment" which further tests the model occurred when exogenous economic and socio-political changes took place in the early Ottoman period. The two primary changes were increased demographic heterogeneity (which limited the coordinative ability of the masses) and decreased external threats (Coşgel, Miceli, and Ahmed 
2009). Both of these changes decreased the ruler's need for legitimacy from religious authorities ( $\gamma$ decreased, though it was still large), since the threat posed by both internal and external rivals was greatly diminished. In turn, the Ottoman sultans brought the religious authority (the mufti hierarchy) into the state, a change which enabled a "limited but significant expansion in the ruler's prerogatives in relation to the shari' a" (Berkey 2003, p. 264).

These changes provide a further test for the theory, which predicts that a relaxation of interest restrictions should follow these events. Indeed, Section 2 notes that interest restrictions were significantly relaxed in this period, although lip service paid to the sharī'a was still necessary to ensure the legality of the contract. Contracts indicating that interest was considered acceptable and in accordance with the shari' $a$ were common, and it is possible that the actions which provided coherence with the sharī'a were never actually carried out. The necessity of including some sort of ruse, however, indicates that neither interest regulations nor the legitimizing relationship were fully undermined, and indeed, religious authorities remained extremely influential vis-à-vis the Ottoman sultans. This history indicates, therefore, that exogenous institutional changes that undermined the legitimizing relations between political and religious authorities $(\gamma)$ - but not the inherent resistance to change $(\alpha)$ - were the driving force behind religious relaxations of interest. Indeed, there is little reason to believe that a change in the religious authorities' inherent resistance to change occurred prior to the relaxations of interest restrictions.

\subsection{The Reversal Effect}

Finally, the model also sheds light on the fact that Islamic interest restrictions were more relaxed than Christian ones until at least the fourteenth century. As noted above, early Islamic religious authorities not only permitted evasions of the interest ban (hiyal), but often created the 
evasions. It can be readily explained why these phenomena occurred centuries before Christian relaxation of interest restrictions: there were greater commercial pressures $(\bar{p})$ for change in the first few Islamic centuries. Yet, the interest ban was not alleviated in early Islamic history, and this created a situation where any future relaxations of Islamic doctrine would have come relative to a more "relaxed" doctrine (higher $\bar{r}$ ) than in Christianity.

Ironically, the model suggests that these early relaxations, combined with a higher degree of initial dependence, may have been the cause of subsequent stagnation of interest restrictions. Because Islamic religious restrictions were relatively relaxed - and there was a higher level of exogenous, initial dependence in these economies - there was less endogenous erosion of the legitimizing relationship over time, as religious authorities chose actions closer to both the political authorities as well as long-established religious precedent.

On the other hand, the Christian interest ban remained quite strong through the thirteenth century. When the Commercial Revolution commenced in the tenth and eleventh centuries, religious authorities maintained the full ban on interest ( $\bar{r}$ was lower (less relaxed) in Christianity than in Islam). However, over the course of the next few centuries, the more restrictive regulations, along with a lower level of dependence, also encouraged actions between political and religious authorities which ultimately undermined dependence.

As noted in Prediction 3, such a "reversal", where Christian interest doctrine was initially less relaxed but ultimately more relaxed than Islamic interest doctrine, could only occur if the dependence relationship is endogenously undermined before the reversal occurs - which is shown to be the case. In other words, although the initial interest regulations in Islam were more relaxed than in Christianity, the endogenous weakening of the legitimizing relationship between political and religious authorities led to a "reversal". 
In all, this analysis by no means is meant to indicate that the interactions between political and religious authorities in relation to economically inhibitive laws were the sole driving force of change in Church-State relations in Europe (and the relative lack of such change in much of the Middle East). ${ }^{30}$ Yet, this history reveals how small exogenous differences in institutional arrangements and initial conditions can have immense consequences. It suggests that the European Commercial Revolution was in part made possible by the exogenous type of relationships between political and religious authorities stemming from the conditions surrounding the birth of Christianity - and it was precisely due to these initial conditions that religious authorities eventually had to adapt to keep up with economic and political change. This is not to say that a Commercial Revolution could not have happened in the Islamic world. As the model suggests, these differing institutional structures merely meant that a larger "shock" was necessary in the Islamic world to precipitate interactions that could undermine the legitimizing power of religious authorities as well as interest restrictions.

These differences were exacerbated by the fact that institutions do not emerge in isolation, but are contingent on historical events, path dependence, and institutional complexes (Kuran 2005; Greif 2006). The interactions between the relevant players pushed the institutional paths of the Islamic world and Western Christendom in vastly different, self-enforcing directions. On the one hand, the interaction between the rise of secular authority and European trade networks supported further economic developments such as complex financial instruments, impersonal exchange, and the corporate form (Greif 1993, 2000, 2006; Kuran 2005; Rubin

\footnotetext{
${ }^{30}$ Indeed, another important difference between the two religions which is not considered in the model is that the pre-Reformation Church was extremely hierarchical while Islamic religious authorities were much more decentralized. Yet, this should work in favor of Islam being the less conservative religion, as jurisdictional competition would encourage innovation and accommodation of custom. For the same reason, it is more likely that Islamic political authorities would be able to bribe religious authorities to relax restrictions, as decentralized Islamic authorities had less power to lose by reinterpreting doctrine and much more to gain relative to their wealth.
} 
2010). On the other hand, the constraints faced in the Islamic world discouraged such a path - or at least, a greater shock was necessary to undermine the political and religious relationship than in Christendom. Instead, less economically beneficial institutions and smaller, personal exchange networks persisted for centuries in the Islamic world (Goitein 1967; Udovitch 1975; Kuran 2001; Greif 2002; Rubin 2010).

\section{The Big Picture: Was the "Gate of Ijtihād" Really Closed?}

This paper tackles an important route through which religion directly impacts economic outcomes: the perpetuation of laws inhibiting economically productive actions. By refraining from attributing anything inherent in religion as the force underlying the economic divergence, this framework encourages a reconsideration of traditional notions of conservatism (based on a preference for conservatism) in the Islamic world. The most influential of these ideas is that the "gate of independent reasoning (ijtihād)" was closed in the tenth century (C.E.). Until recently, historians generally agreed that in this period some informal consensus arose that independent reasoning, an important method of reinterpretation in the first three Islamic centuries, was no longer an acceptable means of finding truth and that henceforth jurists were only allowed to follow precedents (Schacht 1964, ch. 10; Coulson 1969; Weiss 1978). Under this theory, juristic ingenuity was stifled in Sunni Islam after the founding of the four schools consolidated what had been widely dispersed judicial authority. Instead of exercising $i j t i h \bar{a} d$, jurists were confined to accepting religious authority (Hallaq 2001, ch. 4).

Some recent scholarship disputes this notion. Gerber (1999, ch. 4-7) cites myriad cases throughout the medieval period where ijtihād was employed. In a study of rulings by the seventeenth-century Palestinian muftī Khayr al-Dīn al-Ramlī, Gerber notes that numerous 
disagreements which remained unresolved in the classical and post-classical periods arose in alRamli's time, necessitating a relaxation of devotion to the ancient masters. Likewise, Hallaq $(1984,2001)$ notes in great historical detail that the gate of $i j t i h \bar{a} d$ did not close in theory or in practice, though its practice became increasingly rare in the medieval period.

If the gate of ijtihād was not closed, independent reasoning was less frequently practiced after the tenth and eleventh centuries. Indeed, Gerber $(1999$, p. 138) acknowledges that ijtihäd was not freely permitted in every field, but only in those in which the law remained open. In this light, I propose an alternative metaphor: the "gate of ijtihād" may have been closed, but the gate was not locked. All that was necessary for the gate to be opened was for political authorities, merchants, and other interested parties to attempt to push it open. But, due to the incentives supported by the prevailing institutions, few had incentive to "push the gate open", and observed behavior led to the appearance that the gate was closed and locked. The analysis in this paper suggests that there was not necessarily a preference-based inherent "resistance to change" that facilitated conservative outcomes, but instead these results emanated from the incentives put in place by the institutional structure. Indeed, if the gate were not really locked, we might expect to see ijtihād in aspects of law which fostered better economic outcomes, such as those studied by Gerber and Hallaq. However, the overwhelming cost of pushing the gate open when such pressures did not exist was the reason that the gate seemed locked. And once such equilibria emerged in the tenth century, beliefs in the gate's closure were supported, further reinforcing the relationship between Islamic religious and political authorities. This insight allows us to view Islamic legal and economic history through a different lens by looking beyond the scope of observed actions to understand the institutions, behaviors, and incentives underlying them. 


\section{Conclusion}

This paper analyzes the role that religious, political, and legal institutions played in sustaining and undermining economically inhibitive religious laws in medieval Islam and Christianity. I suggest that a salient difference between the two religions' institutional structures is the greater degree to which political authorities were dependent on the dictates of the religious authorities for legitimacy in early Islam. To shed light on the consequences of this difference, I identify the salient players involved in the reinterpretation of religious doctrine (religious and political authorities) and construct a model to identify their interactions under varying institutional conditions. I show that when the initial level of dependence is small, political authorities have incentive to relax regulations on productivity-enhancing actions (such as lending at interest), providing greater incentive for religious authorities to reinterpret "eternal" doctrine even though such reinterpretation endogenously diminishes its ability to bestow legitimacy. The opposite is true when the initial level of dependence is large, and the institutions supporting regulations on productivity-enhancing actions are self-enforcing.

The logic underlying these interactions and outcomes helps account for the salient features of Islamic and Christian interest histories. Moreover, it potentially sheds new light on a variety of historical phenomena in which the interactions between religious institutions and other institutions (political, economic, legal, and social) affected economic outcomes, such as the differing paths of Islamic and Christian laws concerning printing, slavery, insurance, the economic role of women, and education. While significant in their own right, especially given the role that unintended consequences can play in institutional and economic development, studying such cases within the framework presented in this paper provides insight into a much broader economic reality. Contrary to the predilections of many previous scholars, this 
framework turns purely cultural explanations (based on the "conservative nature" of Islam) of the divergence between Western European and Middle Eastern economies on their head. That is, while we certainly see conservative, slowly-changing outcomes in the Islamic world, these phenomena can be understood as a result of the institutional structures and not as a cause of economic stagnation.

\section{References}

Acemoglu, D., Johnson, S. and Robinson, J. (2001). 'The Colonial Origins of Comparative Development: An Empirical Investigation', American Economic Review, vol. 91(5), pp. 1369-1401.

Acemoglu, D., Johnson, S. and Robinson, J. (2005). 'The Rise of Europe: Atlantic Trade, Institutional Change, and Economic Growth', American Economic Review, vol. 95(3), pp. 546-79.

Barro, R. and McCleary, R.M. (2003). 'Religion and Economic Growth Across Countries', American Sociological Review, vol. 68(5), pp. 760-81.

Becker, S.O. and Woessmann, L. (2008). 'Luther and the Girls: Religious Denomination and the Female Education Gap in $19^{\text {th }}$ Century Prussia', Scandinavian Journal of Economics, vol. 110(4), pp. 777-805.

Becker, S.O. and Woessmann, L. (2009). 'Was Weber Wrong? A Human Capital Theory of Protestant Economic History', Quarterly Journal of Economics, vol. 124(2), pp. 531-96.

Berman, H.J. (1983). Law and Revolution: The Formation of the Western Legal Tradition, Cambridge: Harvard University Press.

Berkey, J.P. (2003). The Formation of Islam: Religion and Society in the Near East, 600-1800, Cambridge: Cambridge University Press.

Botticini, M. and Ecksteinm Z. (2005). 'Jewish Occupational Selection: Education, Restrictions, or Minorities?', Journal of Economic History, vol 65(4), pp. 922-48.

Botticini, M. and Ecksteinm Z. (2007). 'From Farmers to Merchants, Conversions and Diaspora: Human Capital and Jewish History', Journal of the European Economic Association, vol. 5(5), pp. 885-926.

Brenner, R. (1983). History - The Human Gamble, Chicago: University of Chicago Press.

Chaudhary, L. and Rubin, J. (2010). 'Reading, Writing, and Religion: Explaining Hindu and Muslim Literacy Differences in Colonial India', Working Paper.

Cipolla, C.M. (1967). Money, Prices, and Civilization in the Mediterranean World: Fifth to Seventeenth Century, Gordian Press: New York.

Clark, G. (2007). A Farewell to Alms: A Brief Economic History of the World, Princeton: Princeton University Press.

Coulson, N.J. (1969). Conflicts and Tensions in Islamic Jurisprudence, Chicago: University of Chicago Press. 
Coşgel, M., and Miceli, T. (2009). 'Church and State,' Journal of Comparative Economics, vol. 37, pp. 402-16.

Coşgel, M., Miceli, T., and Ahmed, R. (2009). 'Law, State Power, and Taxation in Islamic History', Journal of Economic Behavior and Organization, vol. 71, pp. 704-17.

Coşgel, M., Miceli, T., Rubin, J. (2010). 'Guns and Books: Legitimacy, Revolt, and Technological Change in the Ottoman Empire,' Working Paper.

Cromer, E. (1908). Modern Egypt, vol. 2, London: Macmillan.

Çizakça, M. (1995). 'Cash Waqfs of Bursa, 1555-1823', Journal of the Economic and Social History of the Orient, vol. 38, pp. 313-54.

De Roover, R. (1948). Money, Banking, and Credit in Mediceval Bruges, Mediaeval Academy of America: Cambridge, MA.

De Roover, R. (1963). The Rise and Decline of the Medici Bank: 1397-1494, W.W. Norton: New York.

Diamond, J. (1997). Guns, Germs, and Steel: The Fates of Human Societies, New York: Norton.

Divine, T.F. (1959). Interest: an historical and analytical study in economics and modern ethics, Milwaukee: Marquette University Press.

Duby, G. (1980). The Three Orders: Feudal Society Imagined, Chicago: University of Chicago Press.

Ekelund, R.B., Hébert, R.F. and Tollison, R.D. (1989). 'An Economic Model of the Medieval Church: Usury as a Form of Rent Seeking', Journal of Law, Economics, \& Organization, vol. 5(2), pp. 307-31.

Ekelund, R.B., Hébert, R.F., Tollison, R.D., Anderson, G.M. and Davidson, A.B. (1996). Sacred Trust: The Medieval Church as an Economic Firm, Oxford: Oxford University Press.

Engerman, S.L. and Sokoloff, K.L. (2002). 'Factor Endowments, Inequality, and Paths of Development among New World Economies', NBER Working Paper No. 9259.

Feldman, S.M. (1997). Please Don't Wish Me a Merry Christmas: A Critical History of the Separation of Church and State, New York: New York University Press.

Gelpi, R-M, Julien-Labruyère, F. (2000). The History of Consumer Credit: Doctrines and Practices, St. Martin's: New York.

Gerber, H. (1988). Economy and Society in an Ottoman City: Bursa, 1600-1700, Jerusalem: The Hebrew University.

Gerber, H. (1999). Islamic Law and Culture 1600-1840, Leiden: Brill.

Gilchrist, J. (1969). The Church and Economic Activity in the Middle Ages, Macmillan: London.

Glaeser, E. and Scheinkman, J. (1998). 'Neither a Borrower nor a Lender Be: An Economic Analysis of Interest Restrictions and Usury Laws', Journal of Law and Economics, vol. 41(1), pp. 1-36.

Goitein, S.D. (1967). A Mediterranean Society: The Jewish Communities of the Arab World as Portrayed in the Documents of the Cairo Geniza, Vol. 1, University of California Press: Berkeley.

Greif, A. (1993). 'Contract Enforceability and Economic Institutions in Early Trade: The Maghribi Traders' Coalition', American Economic Review, vol. 83(3), pp. 525-48.

Greif, A. (1994). 'Cultural Beliefs and the Organization of Society: A Historical and Theoretical Reflection on Collectivist and Individualist Societies', Journal of Political Economy, vol. 102(5), pp. 912-50.

Greif, A. (2000). 'The Fundamental Problem of Exchange: A Research Agenda in Historical Institutional Analysis', European Review of Economic History, vol. 4(3), pp. 251-284. 
Greif, A. (2002). 'The Islamic Equilibrium: Legitimacy and Political, Social, and Economic Outcomes,' Working Paper, Stanford University.

Greif, A. (2005). 'Commitment, Coercion, and Markets: The Nature and Dynamics of Institutions Supporting Exchange', in (C. Menard and M.M. Shirley, eds.), Handbook for New Institutional Economics, Norwell, MA: Kluwer Academic Publishers.

Greif, A. (2006). Institutions and the Path to the Modern Economy, Cambridge: Cambridge University Press.

Greif, A. and Laitin, D.D. (2004). 'A Theory of Endogenous Institutional Change', American Political Science Review, vol. 98(4), pp. 633-52.

Grice-Hutchinson, M. (1978). Early Economic Thought in Spain, 1177-1740, London: George Allen \& Unwin.

Grier, R. (1997). 'The Effect of Religion on Economic Development: A Cross National Study of 63 Former Colonies', Kyklos, vol. 50(1), pp. 47-62.

Guiso, L., Sapienza, P., and Zingales, L. (2003). 'People's opium? Religion and economic attitudes', Journal of Monetary Economics, vol. 50(1), pp 225-82.

Hallaq, W.B. (1984). 'Was the Gate of Ijtihad Closed?', International Journal of Middle East Studies, vol. 16(1), pp. 3-41.

Hallaq, W.B. (2001). Authority, Continuity, and Change in Islamic Law, Cambridge: Cambridge University Press.

Hallaq, W.B. (2005). The Origins and Evolution of Islamic Law, Cambridge: Cambridge University Press.

Helmholz, R.H. (1986). 'Usury and the Medieval English Church Courts', Speculum, vol. 61(2), pp. 364-80.

Homer, S. and Sylla, R. (1991). A History of Interest Rates, $3^{\text {rd }}$ edition, New Brunswick, NJ: Rutgers University Press.

Ibn Khaldun. (1379/1958). The Muqaddimah: An Introduction to History, 3 vols. (transl. by F. Rosenthal), New York: Pantheon.

Imber, C. (1997). Ebu's-su'ud: The Islamic Legal Tradition, Stanford: Stanford University Press.

Jennings, R.C. (1973). 'Loans and Credit in Early $17^{\text {th }}$ Century Ottoman Judicial Records: The Sharia Court of Anatolian Kayseri', Journal of the Economic and Social History of the Orient, vol. 16(2/3), pp. 168-216.

Jones, E.L. (1981). The European Miracle: Environments, Economics, and Geopolitics in the History of Europe and Asia, Cambridge: Cambridge University Press.

Jones, E.L. (1988). Growth Recurring: Economic Change in World History, Oxford: Clarendon Press.

Jones, P. (1997). The Italian City-State: From Commune to Signoria, Oxford: Clarendon Press.

Khan, M.S.A. (1929). 'The Mohammedan Laws against Usury and How They Are Evaded', Journal of Comparative Legislation and International Law, vol. 11, pp. 233-44.

Kindleberger, C.P. (1980). 'Review of the dawn of modern banking by the center for medieval and renaissance', Journal of Political Economy, vol. 88(1), pp. 217-219.

Koyama, M. (2010). 'Evading the 'Taint of Usury': Complex Contracts and Segmented Capital Markets', Explorations in Economic History, forthcoming

Kuran, T. (1986). 'The economic system in contemporary Islamic thought: Interpretation and assessment', International Journal of Middle East Studies, vol. 18, pp. 135- 164.

Kuran, T. (1995). Private Truths, Public Lies: The Social Consequences of Preference Falsification, Cambridge: Harvard University Press. 
Kuran, T. (1997). 'Islam and underdevelopment: An old puzzle revisited', Journal of Institutional and Theoretical Economics, vol. 153(1), pp. 41-71.

Kuran, T. (2001). 'The Provision of Public Goods under Islamic Law: Origins, Impact, and Limitations of the Waqf System', Law and Society Review, vol. 35(4), pp. 841-97.

Kuran, T. (2003). 'The Islamic Commercial Crisis: Institutional Roots of Economic Underdevelopment in the Middle East', Journal of Economic History, vol. 63(2), pp. 414-46.

Kuran, T. (2005). 'The Absence of the Corporation in Islamic Law: Origins and Persistence', The American Journal of Comparative Law, vol. 53, pp. 785-834.

Labib, S.Y. (1969). 'Capitalism in Medieval Islam', Journal of Economic History, vol. 29, pp. 79-96.

Landes, D.S. (1998). The Wealth and Poverty of Nations: Why Some Are So Rich and Some So Poor, New York: W.W. Norton.

Lane, F.C. (1966). Venice and History: The Collected Papers of Frederic C. Lane, Johns Hopkins Press: Baltimore.

Le Goff, J. (1979). 'The Usurer and Purgatory', in (Center for Medieval and Renaissance Studies, eds.), The Dawn of Modern Banking, New Haven: Yale University Press.

Le Goff, J. (1988). Your Money or Your Life: Economy and Religion in the Middle Ages, Cambridge: MIT Press.

Lewis, B. (1974). Islam: From the Prophet Muhammad to the Capture of Constantinople, New York: Harper \& Row.

Lewis, B. (1982). The Muslim Discovery of Europe, New York: Norton.

Lewis, B. (1993). Islam and the West, Oxford: Oxford University Press.

Lewis, B. (1995). The Middle East, New York: Scribner.

Lewis, B. (2002). What Went Wrong? The Clash Between Islam and Modernity in the Middle East, New York: HarperCollins.

Libson, G. (1997). 'On the Development of Custom as a Source of Law in Islamic Law: Alrujū'u ilā al-'urfi ahadu al-qawā'idi al'khamsi allatī yatabannā 'alayhā al-fiqhu', Islamic Law and Society, vol. 4(2), pp. 131-55.

Lopez, R.S. (1971). The Commercial Revolution of the Middle Ages, 950-1350, Cambridge: Cambridge University Press.

Mann, M. (1986). The Sources of Social Power: A history of power from the beginning to A.D. 1760, Cambridge: Cambridge University Press.

Masud, M.K., Messick, B. and Powers, D.S. (1996). 'Muftis, Fatwas, and Islamic Legal Interpretation', in (M.K. Masud, B. Messick and D.S. Powers, eds.), Islamic Legal Interpretation: Muftis and their Fatwas, Cambridge: Harvard University Press.

Meyersson, E. (2009). 'Islamic Rule and the Emancipation of the Poor and Pious', Working Paper.

Mokyr, J. (1990). The Lever of Riches, Oxford: Oxford University Press.

Mueller, R. (1997). The Venetian Money Market: Banks, Panics, and the Public Debt, 12001500, Johns Hopkins University Press: Baltimore.

Munro, J. (2003). 'The Medieval Origins of the Financial Revolution: Usury, Rentes, and Negotiablity', The International History Review, vol. 25(3), pp. 505-62.

Munro, J. (2008). 'The usury doctrine and urban public finances in late-medieval Flanders (1220-1550): Rentes (annuities), excise taxes, and income transfers from the poor to the rich', in (S.Cavaciocchi, ed.), La fiscalità nell'economia europea. Secc. XIII-XVIII Fiscal 
Systems in the European Economy from the 13th to the 18th Centuries, vol. 39, University of Florence Press: Florence.

Noland, M. (2005). 'Religion and Economic Performance'. World Development, vol. 33(8), pp. 1215-32.

Noonan, J.T. (1957). The Scholastic Analysis of Usury, Cambridge: Harvard University Press.

Noonan, J.T. (1966). 'Authority, usury, and contraception', Cross Currents, vol. 16(1), pp. 5579.

Noonan, J.T. (1993). 'Development in Moral Doctrine', Theological Studies, vol. 54, pp. 662-77.

Noonan, J.T. (2005). A Church that Can and Cannot Change, Notre Dame: University of Notre Dame Press.

North, D.C. (1981). Structure and Change in Economic History, New York: W.W. Norton.

North, D.C. and Thomas, R.P. (1973). The Rise of the Western World: A New Economic History, Cambridge: Cambridge University Press.

Pamuk, Ş. (2004). 'Institutional Change and the Longevity of the Ottoman Empire, 1500-1800', Journal of Interdisciplinary History, vol. 35, pp. 225-47.

Persky, J. (2007). 'Retrospectives: From Usury to Interest', Journal of Economic Perspectives, vol. 21(1), pp. 227-36.

Pomeranz, K.L. (2000). The Great Divergence: China, Europe, and the Making of the Modern World Economy, Princeton: Princeton University Press.

Rahman, F. (1964). 'Ribā and Interest', Islamic Studies, vol. 3, pp. 1-43.

Ray, N.D. (1997). 'The Medieval Islamic System of Credit and Banking: Legal and Historical Considerations', Arab Law Quarterly, vol. 12, pp. 43-90.

Rodinson, M. (1973). Islam and Capitalism, Austin: University of Texas Press.

Rubin, J. (2008). 'Printing and Interest Restrictions in Islam \& Christianity: An Economic Theory of Inhibitive Law Persistence', Working paper.

Rubin, J. (2009). 'Social Insurance, Commitment, and the Origin of Law: An Economic Theory of the Emergence of Interest Bans', Journal of Law \& Economics vol. 52(4), pp. 761777.

Rubin, J. (2010). 'Bills of Exchange, Interest Bans, and Impersonal Exchange in Islam and Christianity', Explorations in Economic History vol 47(2), pp. 213-227.

Schacht, J. (1964). An Introduction to Islamic Law, Oxford: Oxford University Press.

Schacht, J. (1995). 'Ribā', in (C.E. Bosworth, E. van Donzel, W.P. Heinrichs, G. Lecomte, Eds.), The Encyclopaedia of Islam: New Edition, Brill: Leiden.

Schacht, J. (2006). 'Hiyal', in Encyclopaedia of Islam Online Edition, $2^{\text {nd }}$ edition.

Tawney, R.H. (1926) 1954. Religion and the Rise of Capitalism, New York: Mentor.

Tierney, B. (1988). The Crisis of Church and State 1050-1300, Toronto: University of Toronto Press.

Udovitch, A.L. (1970). Partnership and Profit in Medieval Islam, Princeton University Press: Princeton.

Udovitch, A.L. (1975). 'Reflections on the Institutions of Credits and Banking in the Medieval Islamic Near East', Studia Islamica, vol. 41, pp. 5-21.

Udovitch, A.L. (1979). 'Bankers without Banks: Commerce, Banking, and Society in the Islamic World of the Middle Ages', in (Center for Medieval and Renaissance Studies, eds.), The Dawn of Modern Banking, New Haven: Yale University Press, pp. 255-273

von Grunebaum, G.E. (1966). Medieval Islam: A Study in Cultural Orientation, Chicago: University of Chicago Press. 
Weber, M. (1905) 2002. The Protestant Ethic and the 'Spirit' of Capitalism, New York: Penguin. Weber, M. (1922) 1978. Economy and Society: An Outline of Interpretive Sociology, Berkeley: University of California Press.

Weiss, B. (1978). 'Interpretation in Islamic Law: The Theory of Ijtihad', American Journal of Comparative Law, vol. 26, pp. 199-212.

Zubaida, S. (2003). Law and Power in the Islamic World, New York: I.B. Tauris \& Co. 


\section{FIGURES}

Figure 1: Reversal in Religious Interpretation

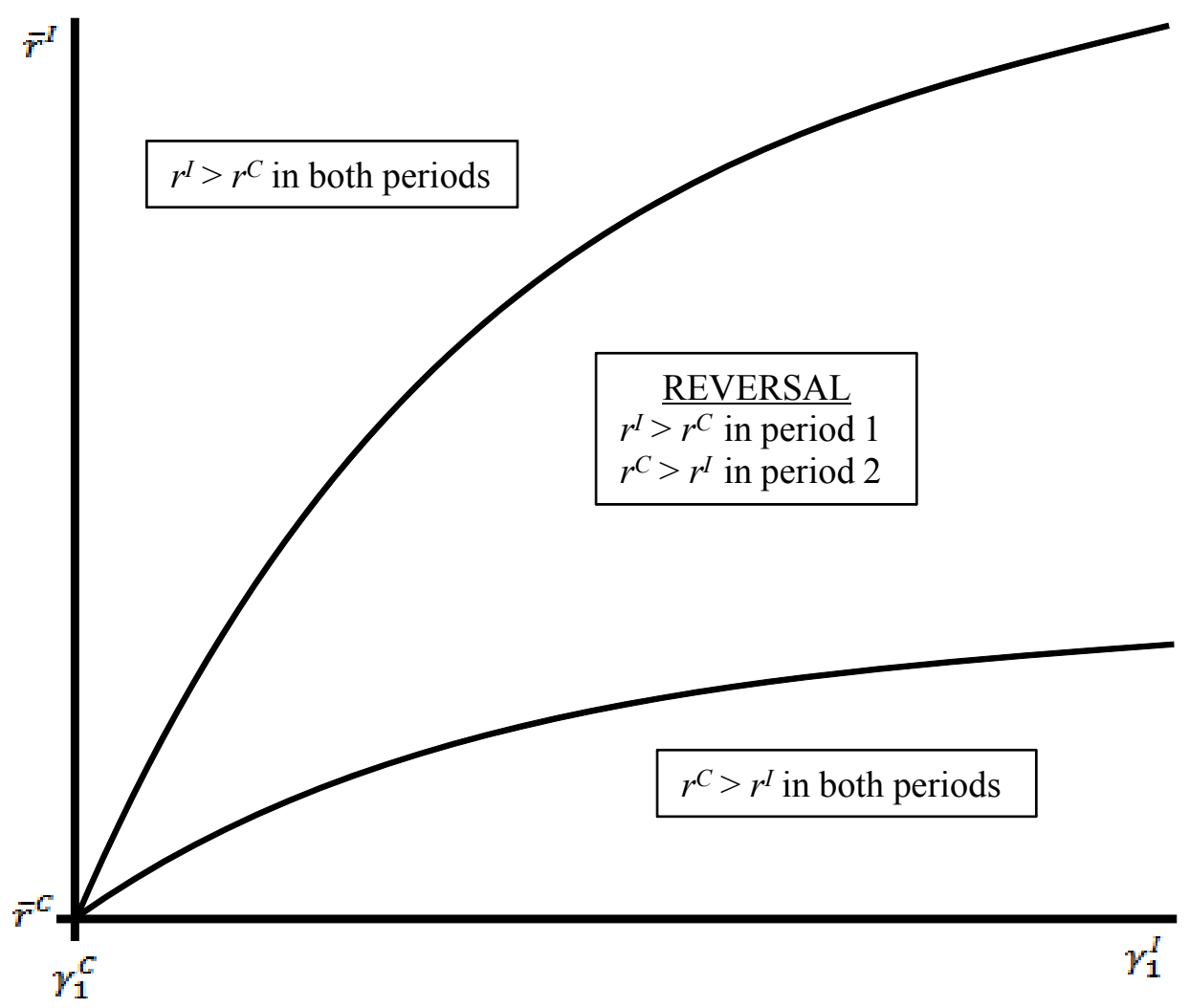

